\title{
Review of the bennettitalean genus Weltrichia
}

\author{
Mihai Emilian Popa(D)
}

\begin{abstract}
The bennettitalean male reproductive structure Weltrichia Braun 1849 emend. Harris 1969 (Family Williamsoniaceae) is discussed from several points of view, including anatomy and morphology, species diversity and validity, phytogeographical and stratigraphical distribution, and reproduction strategy. A very rare fossil, genus Weltrichia includes 25 valid species distributed in both hemispheres during Triassic and Jurassic times. This contribution critically reviews the systematics of the entire genus, together with its stratigraphical and palaeophytogeographical significance.
\end{abstract}

Keywords: Bennettitales, Weltrichia, Male reproductive structure, Triassic, Jurassic

\section{Introduction}

The Order Bennettitales Engler 1892 represents a highly interesting group of extinct gymnosperms in terms of anatomy, high biodiversity and widespread phytogeographical distribution during the whole Mesozoic (Stewart 1983; Taylor et al. 2009; Friis et al. 2011). In the same time, their evolutionary significance is related to the origin of angiosperms, as the Bennettitales innovated radial, complex, unisexual or bisexual reproductive structures resembling the angiosperm flowers. Such reproductive structures are true gymnospermous cones and they represent a convergent evolutionary trend with true flowers, an experiment which the Bennettitales undertook before the first flowering plants originated (Friis et al. 2011; Pott 2014). The reproductive structures resembling flowers were not the only peculiar characters of Bennettitales, they also possessed syndetocheilic stomata in their epidermal tissues. These types of stomata separate them from morphologically similar vegetative organs of plants belonging to the Order Cycadales, among other characters. Bennettitales are related to Gnetales and angiosperms in cladistic studies (Doyle 2006; Hilton and Bateman 2006). They are divided into two separate families, based on vegetative and reproductive anatomy: Family Williamsoniaceae, dominantly with Late Triassic and Jurassic representatives, and Family Cycadeoidaceae (Bennettitaceae), with mainly

Correspondence: mihai@mepopa.com

Faculty of Geology and Geophysics, Department of Geology and Doctoral School of Geology, Laboratory of Palaeontology, University of Bucharest, 1, N. Bălcescu Ave, 010041 Bucharest, Romania
Cretaceous representatives. The Williamsoniaceae includes plants with a slender stem and unisexual and bisexual reproductive structures, such as the unisexual, male Weltrichia Braun 1849 emend Harris 1969, the female Williamsonia Carruthers 1870 or the bisexual Williamsoniella Thomas 1915.

Weltrichia consists basically of a central cup to which radially equal, centrifugal rays are attached, bearing bivalve pollen sacs (also called synangia) with elliptical, monocolpate pollen, the whole structure having a radial symmetry. The substance of the cup and rays is usually thick, and the rays occur in a single whorl. Variations to this basic morphology include equal centripetal rays over the central cup, attractants or resin (resinous) bodies within the cup, unipinnate (pedicellate) pollen sacs, trichomes, appendages, striae and ridges over the centrifugal rays. Weltrichia is associated with Williamsonia female reproductive structures, with foliage belonging to the genera Zamites, Otozamites and Ptilophyllum and with other vegetative parts such as Bucklandia cortical fragments (Harris 1969).

Genus Weltrichia was defined by Braun (1849), with the type species Weltrichia mirabilis from Lower Jurassic sediments of Franconia, Germany. He also defined two more species of Weltrichia in the same paper, synonyms of $W$. mirabilis. The new taxon was dedicated to Johann P. A. Weltrich, who collected the material, and it was considered as belonging to the Family Rafflesiaceae (Braun 1849). Initially, the Weltrichia denomination did not reach a wide use, as such 
structures were often referred as "male Williamsonias", in relation with and resembling the female bennettitalean reproductive structures Williamsonia Carruthers 1870. Krasser (1912, 1913, 1915, 1919, 1922), Nathorst (1909, 1911a, 1912) and Sharma (1969) used the term "male Williamsonia" for various Weltrichia species, while Schuster (1911) and Nathorst (1911b) used Weltrichia. Saporta (1891) used Weltrichia in his contribution on Jurassic plants of France, erecting two new species, W. fabrei from France and W. oolithica from Italy. Discussion over the relationship between Weltrichia and Williamsonia and on their nomenclature was continued by Harris (1969), Sitholey and Bose (1971), Schweitzer and Kirchner (2003) and Popa (2014), next to emendations of previous species or with definitions of new species. As Weltrichia has priority over Williamsonia, it was kept by Harris (1969) as a legitimate denomination for male, unisexual structures, keeping Williamsonia only for female, unisexual structures. Harris (1969) emended the diagnosis of the genus, supplementing it with microscopical characters, noting the high variation in attaching the pollen sacs to the centrifugal rays, directly or on supplementary, sterile appendages. Harris refrained from splitting the genus and erecting new genera based on this variation of characters, for practical reasons. Popa (2014) briefly reviewed the valid species of Weltrichia and their ranges when introducing new species of this genus, stressing the most important characters in Weltrichia: shape and number of centrifugal rays, ornamentation and shape of centripetal rays, distribution and types of pollen sacs, ornamentation of the central cup, and occurrence of resin bodies.
Since Braun (1849), Weltrichia species were described from Franconia, Germany (Schuster 1911), Banat, Romania (Krasser 1915, 1922; Humml 1969; Givulescu 1990, 2001, 2014), Yorkshire, United Kingdom (Nathorst 1909, 1911a, 1911b, 1912, 1913; Florin 1933; Harris 1969), Tirol, Germany (Krasser 1919), Veneto and Sardinia, Italy (Saporta 1891; Krasser 1912), France (Saporta 1891), Alborz Mountains, Iran (Schweitzer and Kirchner 2003), Rajmahal, Malda and Katchchh, India (Sharma 1969, 1971, 1977; Sitholey and Bose 1971; Bose and Banerji 1984; Pal and Ghosh 1985; Banerji 1992), Malaysia (Asama 1974), Nepal (Kimura et al. 1985), China (Sun et al. 2001; Li et al. 2004), Japan (Kimura and Ohana 1989) and Oaxaca, Mexico (Delevoryas and Gould 1973; Delevoryas 1991; Silva Pineda et al. 2011; Velasco de Leon et al. 2012). The distribution of Weltrichia species in the world is illustrated in Fig. 1.

The stratigraphic ranges of Weltrichia species vary from Late Triassic to Late Jurassic, from the earliest representative Weltrichia alpina, Late Triassic in age, to its latest representatives, W. maldaensis and W. huangbanjigouensis, Late Jurassic in age.

\section{Material and methods}

The Romanian material belonging to genus Weltrichia has been surveyed and described in a previous work (Popa 2014), curated at the University of Bucharest and at University of Petroșani. Previous palaeobotanical literature was carefully surveyed and large sized differential tables were synthesized. I have produced the reconstructions

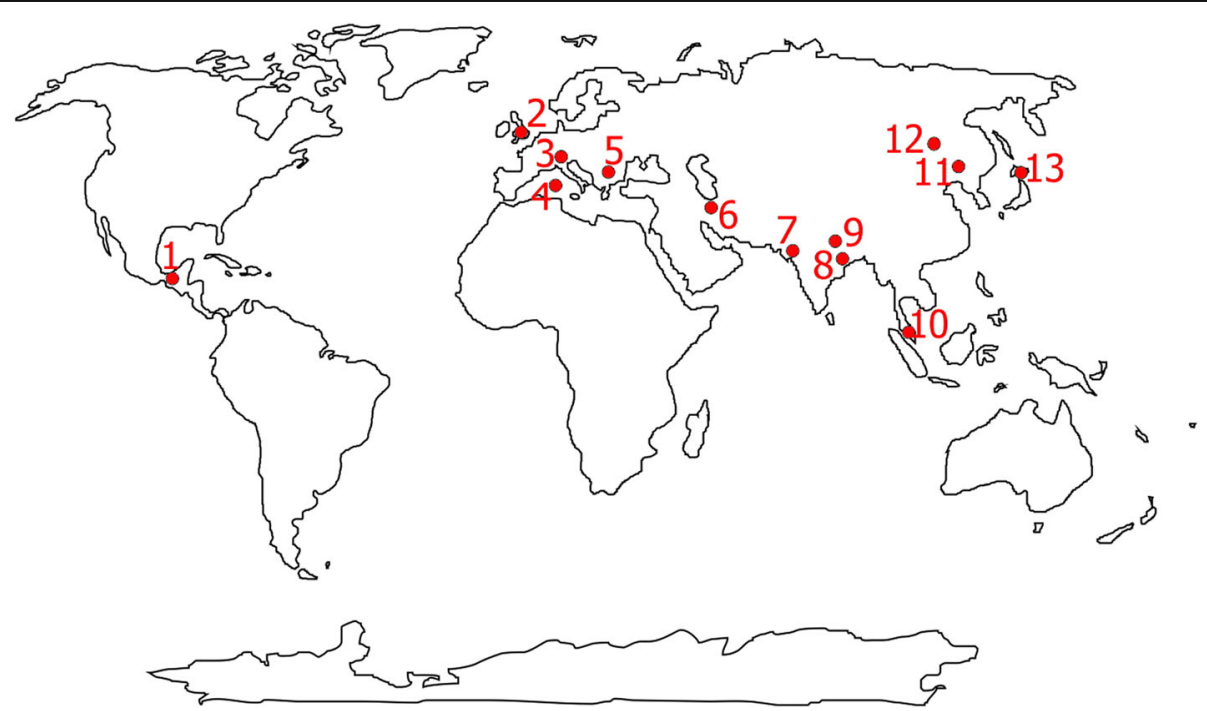

Fig. 1 Geographical distribution of genus Weltrichia. 1. Oaxaca State (Mexico); 2. Yorkshire (United Kingdom); 3. Tirol, Franconia (Germany), Veneto (Italy), Lozére (France); 4. Sardinia (Italy); 5. Anina (Romania); 6. Alborz (Iran); 7. Kachchh (India); 8. Rajmahal and Malda (India); 9. Palpa (Nepal); 10. Ulu Endau (Malaysia); 11. Liaoning (China); 12. Chifeng (Inner Mongolia Autonomous Region, China); 13. Samenoura (Japan) 
manually, using a protractor, a ruler, a pair of compasses and soft lead $0.5 \mathrm{~mm}$ mechanical pencils (2B), as well as normal and semi-transparent paper for continuously refining the drawings. The numbers of centrifugal and centripetal rays were considered, in order to divide angles and circles accordingly, while ray lengths, widths and diameters of central cups were reflected in reconstructions, for correct dimensional ratios in drawings. All dimensions and preserved anatomical and morphological characters were considered in order to produce accurate reconstructions. Drawings with adaxial and abaxial perspectives were produced, depending on the preservation of the original fossil material. Some reconstructions are more detailed, such as the reconstructions of Weltrichia givulescui (Fig. 8), W. pecten (Fig. 15), W. setosa (Fig. 16), W. sol (Fig. 17), and W. spectabilis (Fig. 19), as they possess better preserved fossil material than other species. Other species have less detailed reconstructions, such as those belonging to Weltrichia alpina (Fig. 4), W. antonii (Fig. 5), W. sp. (Fig. 18), and W. steierdorfensis (Fig. 20), as their fossil material is less preserved. Vectorial images (Figs. 1, 2) were generated using CorelDRAW ver. X7 software.

\section{Terminology}

The terminology used in Weltrichia parts is very variable and sometimes confusing. Harris (1969) used the terms central cup, rays or microsporophylls and pollen sacs for the main parts of Weltrichia, as well as resin or resinous bodies (sometimes also called resinous sacs), sterile scales, and fertile appendages (Fig. 2). The preference for pollen sacs instead of synangia was explained for the gymnospermous nature of Weltrichia (Harris 1969, p. 159), in contrast with the more pteridophytic synangia. Although the term synangia is also correctly used for these structures (Pott et al. 2017), pollen sacs being basically synonym to synangia, I also use here the term pollen sacs (Fig. 2). The terms centrifugal rays, instead of just rays or microsporophylls (another perfectly correct synonym for centrifugal rays) and centripetal rays instead of sterile scales describe better the form and function of these Weltrichia parts (Fig. 2). The term median ridge is preferred in this paper to synonym terms such as midrib, middle ridge or central rib.

\section{Systematics}

Harris (1969) emended the diagnosis of genus Weltrichia: "Bennettitalean male flower consisting of a massive

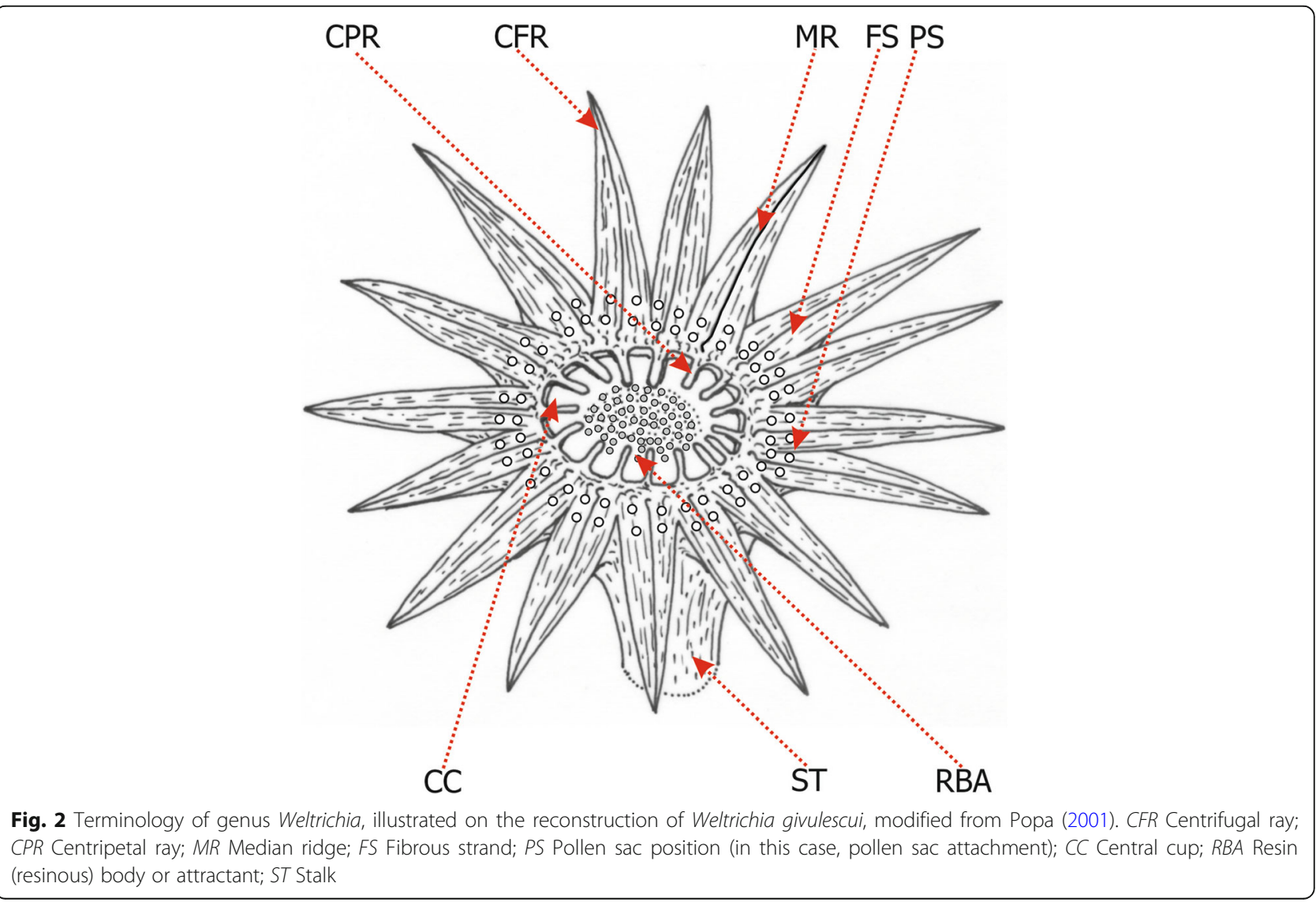




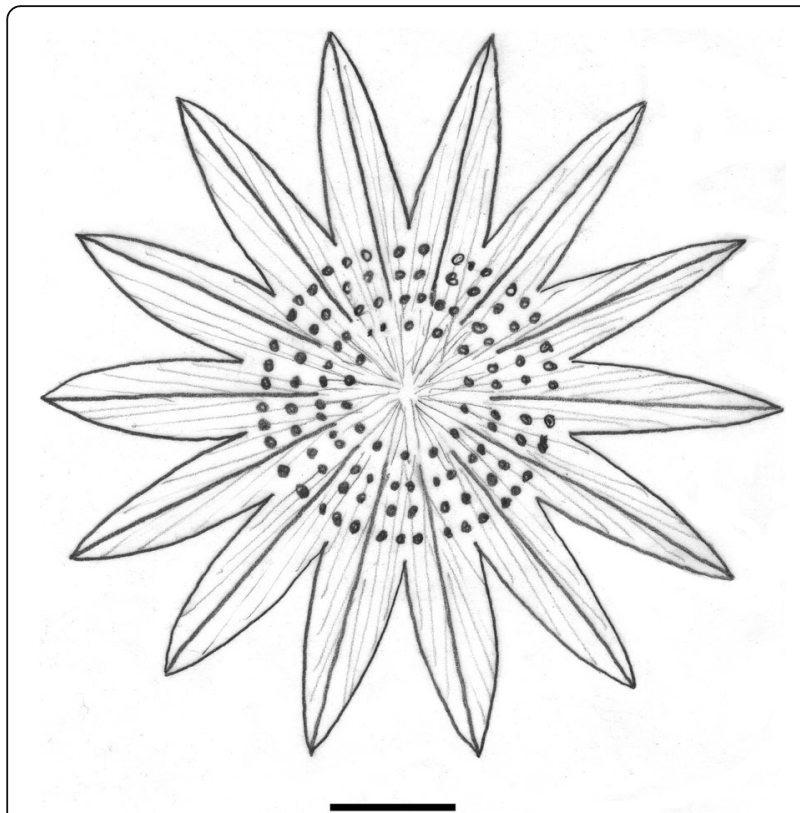

Fig. 3 Reconstruction of Weltrichia alfredii (Krasser) Popa 2014, Sinemurian, Steierdorf Formation, Valea Tereziei Member, Anina, South Carpathians, Romania. The centrifugal rays have numerous fibrous strands and the central cup has resin bodies or attractants. Adaxial view, scale bar: $20 \mathrm{~mm}$

cup dividing above into numerous equal lobes or rays; rays of thick substance, tapering to a point. Outer surface of cup and rays without appendages. Cuticles (where known) showing syndetocheilic stomata with single subsidiary cell opposite each guard cell. Inner side of cup and of rays bearing pollen sacs, either directly, or on appendages. Pollen sacs (synangia) where known consisting of two equal valves, each valve with a single row of microsporangia opening on to inner face. Pollen grains oval, monocolpate". Twenty five valid species of Weltrichia were described from the Triassic and Jurassic formations of the world.

\subsection{Weltrichia alfredii (Krasser) Popa 2014 (Fig. 3)}

Weltrichia alfredii is $120 \mathrm{~mm}$ in external outline diameter, with a central cup about $54-55 \mathrm{~mm}$ in diameter, $10 \mathrm{~mm}$ deep, with a thick substance, ornamented with fine radial striae and prominent adaxial ridges continued along each centrifugal ray. Abaxial surfaces of the centrifugal rays are smooth and planar, while the adaxial surfaces have a strong median ridge. The central cup has regularlyarranged tubercles along its adaxial surface, which acted probably as attractants or as resin bodies, as they look thick and dense. The species has 13-14 thick centrifugal rays, triangular-elongated in shape, with slightly-curved margins; they are $30-32 \mathrm{~mm}$ long and 10-12 $\mathrm{mm}$ wide at the base, next to the central cup. Both cup and rays have radial fibers embedded in their thick substance. No

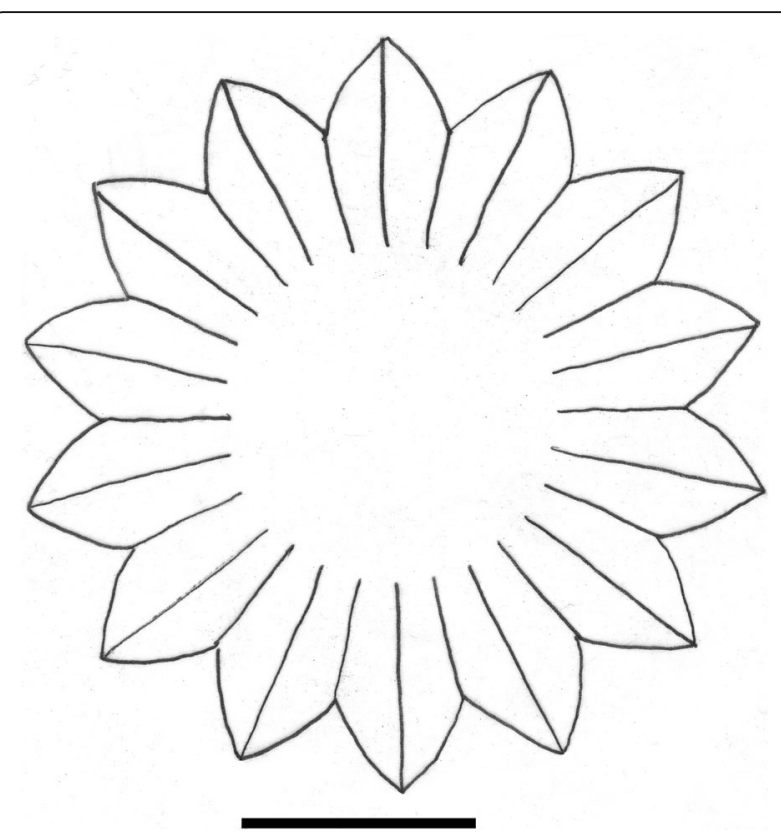

Fig. 4 Reconstruction of Weltrichia alpina Krasser 1919, Late Triassic, southern Tirol, Germany. A poorly preserved species, Weltrichia alpina has few known morphological characters. Adaxial view, scale bar: $20 \mathrm{~mm}$

centripetal rays and pollen sacs are known (Fig. 3). Although it lacks pollen sacs, this species is better understood after new findings in the South Carpathians (Popa 2014). Its systematic affinities lay with Weltrichia pecten and W. whitbiensis (Harris 1969; Popa 2014). Weltrichia alfredii is associated with Ptilophyllum sp. foliage. It has been defined and described by Krasser (1922) and emended by Popa (2014) from Anina, South Carpathians, Romania, within the Steierdorf Formation, Valea Tereziei Member, where it is Sinemurian in age. Anina, formerly known as Steierdorf, is a fossile-Lagerstatte locality for both preservation and biodiversity (Popa 1997, 2014). The holotype was lost (Popa 2014). The repository of the neotype and of the rest of the type series, including one paratype, is at the Laboratory of Palaeontology, Department of Geology, Faculty of Geology and Geophysics, University of Bucharest, Bucharest, Romania.

\subsection{Weltrichia alpina Krasser 1919 (Fig. 4)}

A small sized Weltrichia species, W. alpina is about 54 $\mathrm{mm}$ in diameter, with a wide central cup and 14 short centrifugal rays with rounded margins and sharp apices. Excepting a low median ridge along the rays, the ornamentation of the cup or of the rays is unclear, with no pollen sacs recorded. Krasser (1919) gave a sketch drawing of this species, and its outline is here shown (Fig. 4). Knowledge on this species is rather poor, as the degree of preservation of the holotype is rather poor as 


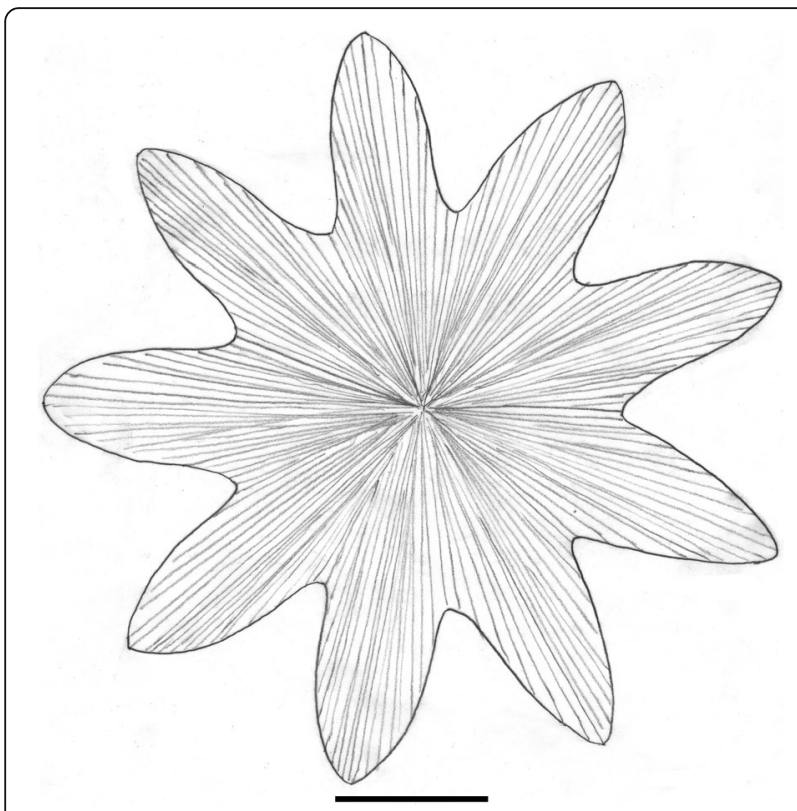

Fig. 5 Reconstruction of Weltrichia antonii Popa 2014, with fibrous strands and a very low number of centrifugal rays. Sinemurian, Steierdorf Formation, Valea Tereziei Member, Anina, South Carpathians, Romania. Abaxial view, scale bar: $20 \mathrm{~mm}$

well. Weltrichia alpina is rather unique, with its size and short centrifugal rays. It is not associated with any other organs. Krasser (1919) published it as a male Williamsonia species and Popa (2014) assigned it to Weltrichia. It was collected from the Cassian Beds, southern Tirol, Germany, and it is Late Triassic in age, therefore it is the oldest species of Weltrichia. The repository of the holotype is unknown.

\subsection{Weltrichia antonii Popa 2014 (Fig. 5)}

Weltrichia antonii is $100 \mathrm{~mm}$ in diameter, with a central cup diameter of $52 \mathrm{~mm}$. The central cup is smooth, with a moderately thick substance, with fine, radial fibrous strands, a cup height of 5-7 mm. It has 9-10 centrifugal rays which are short triangular, with rather smooth surfaces, with slightly rounded apices, decurrent and wide bases, $25 \mathrm{~mm}$ long and $13 \mathrm{~mm}$ wide at their base, and with no known centripetal rays and pollen sacs. The substance of the rays is moderately thick, and it has fine fibrous strands (Fig. 5). The main peculiarity of Weltrichia antonii is the reduced number of centrifugal rays (9-10), the lowest number of rays recorded in the genus. It has no apparent affinities with other Weltrichia species. Schweitzer and Kirchner (2003) published a Weltrichia sp. A from Nessen, Alborz Mountains, Iran, Middle Jurassic in age, resembling superficially W. antonii. Weltrichia antonii is associated with a single Ptilophyllum sp. leaf fragment, and it was collected from Anina, Banat region, South Carpathians, Romania, within

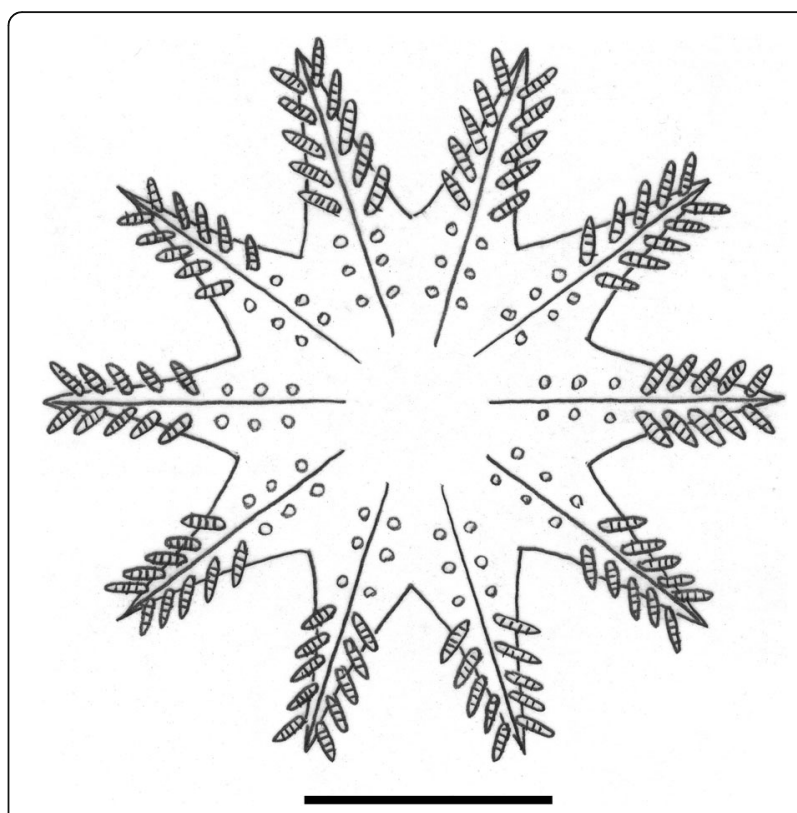

Fig. 6 Reconstruction of Weltrichia ayuquiliana Delevoryas 1991, Middle Jurassic, Tecomazuchil Formation, Oaxaca State, Mexico. The elongated pollen sacs occurring on the adaxial surface of the centrifugal rays continue inside the central cup of the reproductive structure. Adaxial view, scale bar: $20 \mathrm{~mm}$

the Steierdorf Formation, where it is Sinemurian in age (Popa 2014). The holotype is the only known fragment and it is stored at the Laboratory of Palaeontology, Department of Geology, Faculty of Geology and Geophysics, University of Bucharest, Bucharest, Romania.

\subsection{Weltrichia ayuquiliana Delevoryas 1991 (Fig. 6)}

This species is rather small, about $60 \mathrm{~mm}$ in outer diameter, with a stalked central cup, $30 \mathrm{~mm}$ in diameter, and with a stalk diameter of $15 \mathrm{~mm}$. To the central cup are attached ten short centrifugal rays, $15 \mathrm{~mm}$ long, triangular, with entire margins and acute apices. The rays have a strong median ridge reaching the apex, expressed on both their sides. The pollen sacs are attached on the adaxial surface, in two rows per ray, on both sides of the median ridge, occurring continuously also into the central cup. The pollen sacs are elliptical, elongated, $6 \mathrm{~mm}$ long and $2 \mathrm{~mm}$ wide, bearing sporangia (Fig. 6). No pollen grains were recorded. Weltrichia ayuquiliana is quite peculiar in size and in the low number of centrifugal rays. In number of rays it resembles only Weltrichia antonii, which has only nine rays, but the latter is much larger in size, with narrower centrifugal rays. Weltrichia ayuquiliana is not associated with other bennettitalean organs. Delevoryas (1991) argued that the bodies inside the central cup must be pollen sacs, as they are too substantial, but the occurrence of resin bodies or attractant bodies is quite possible too. Silva Pineda et al. (2011) and Velasco de Leon et al. (2012) discussed the 


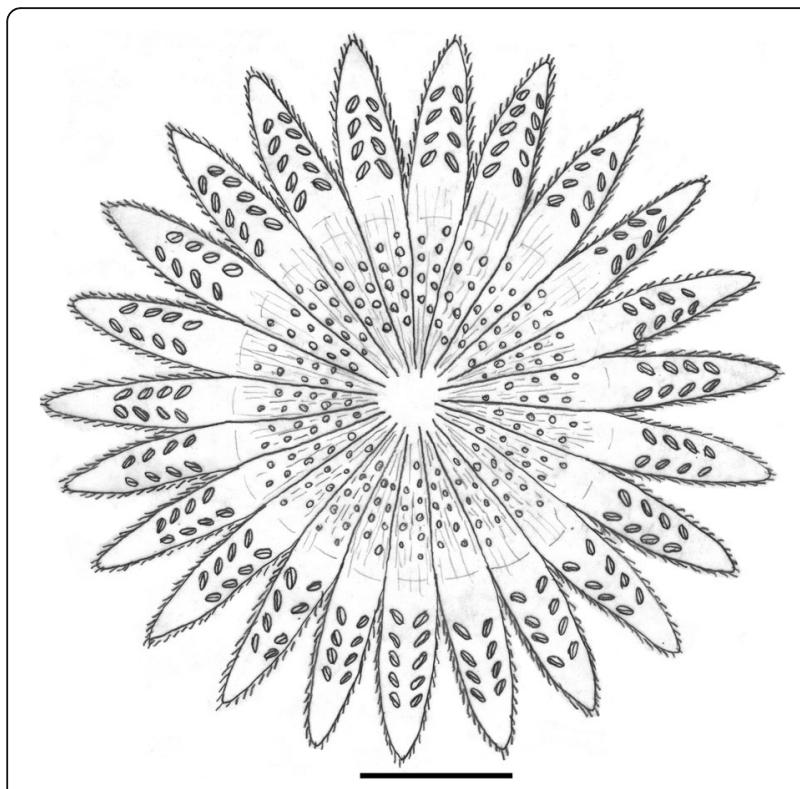

Fig. 7 Reconstruction of Weltrichia daohugouensis Li et al. 2004, Middle Jurassic, Daohugou, Inner Mongolia Autonomous Region, China. The centrifugal rays are hairy, with elliptical, bivalve pollen sacs while the central cup shows fibrous strands and resin bodies or pollen sacs. Adaxial view, scale bar: $20 \mathrm{~mm}$

occurrence of this species. This structure was collected from the Tecomazuchil Formation, near Pena de Ayuquila, $15 \mathrm{~km}$ northwest from Huajuapan de Leon, Oaxaca State, Mexico. It is Middle Jurassic in age. The holotype is stored at University of Texas, Austin, Texas, United States of America.

\subsection{Weltrichia daohugouensis Li et al. 2004 (Fig. 7)}

Weltrichia daohugouensis has a $48-50 \mathrm{~mm}$ in diameter central cup which is finely striated radially, fibrous, with resin bodies or incompletely-developed pollen sacs. The diameter of the structure is $98-100 \mathrm{~mm}$. To the central cup are connected about 22-23 centrifugal rays with striations and fibers which continue from the central cup, as the cup seems generated by the fusion of the basal parts of the centrifugal rays, therefore creating circular sectors. The centrifugal rays are $20-25 \mathrm{~mm}$ long and $4-5 \mathrm{~mm}$ wide to their middle part, with slightly acute apices. The abaxial surface of the centrifugal rays is hairy, while the adaxial surface is rather smooth, yielding two parallel rows of pollen sacs grouped in the second, apical part of the rays (Fig. 7). The pollen sacs are elliptic, flattened, made of two valves, occurring obliquely to the centrifugal ray axis, $2 \mathrm{~mm}$ long and 1-1.5 $\mathrm{mm}$ wide in their middle part. Each valve has about 7-8 sporangia with elliptical, monosulcate pollen grains, $40 \mu \mathrm{m}$ long and $20 \mu \mathrm{m}$ wide ( $\mathrm{Li}$ et al. 2004). No centripetal rays were recorded. The peculiarities of $\mathrm{Wel}$ trichia daohugouensis include the short, abaxially hairy centrifugal rays in high numbers and the pollen sacs. It is a well understood and defined species, based on well preserved material. However, the number of centrifugal rays may be higher than 22-23, as the holotype shows 11 rays which cover less than half of the central cup. It is associated with Cycadolepis sp. This species was collected from Daohugou village, Shantou town, Nincheng county, Chifeng City, Inner Mongolia Autonomous Region, China, from the Middle Jurassic Haifanggou Formation. The material includes only the holotype, probably stored in Shenyang, Liaoning Province, China.

\subsection{Weltrichia fabrei Saporta 1891}

The central cup is probably not preserved in the material. The centrifugal rays are $50-60 \mathrm{~mm}$ long in fragmented state. $8-10 \mathrm{~mm}$ wide in the lower part of the fragments, they are striated longitudinally along their abaxial surface, with entire margins, with a tendency of curving inwards. Pollen sacs are elongated, narrow, 3-4 $\mathrm{mm}$ long and $1 \mathrm{~mm}$ wide, inserted along two parallel rows on the adaxial surface of the centrifugal rays (Saporta 1891). Due to the poor state of preservation and to the scarcity of the material, this species is less understood, and the total number of centrifugal rays cannot be deduced or reconstructed. I refrain from proposing a reconstruction. It has strong similarities with Weltrichia mirabilis in shape of the centrifugal rays and of the pollen sacs. No other bennettitalean organs were

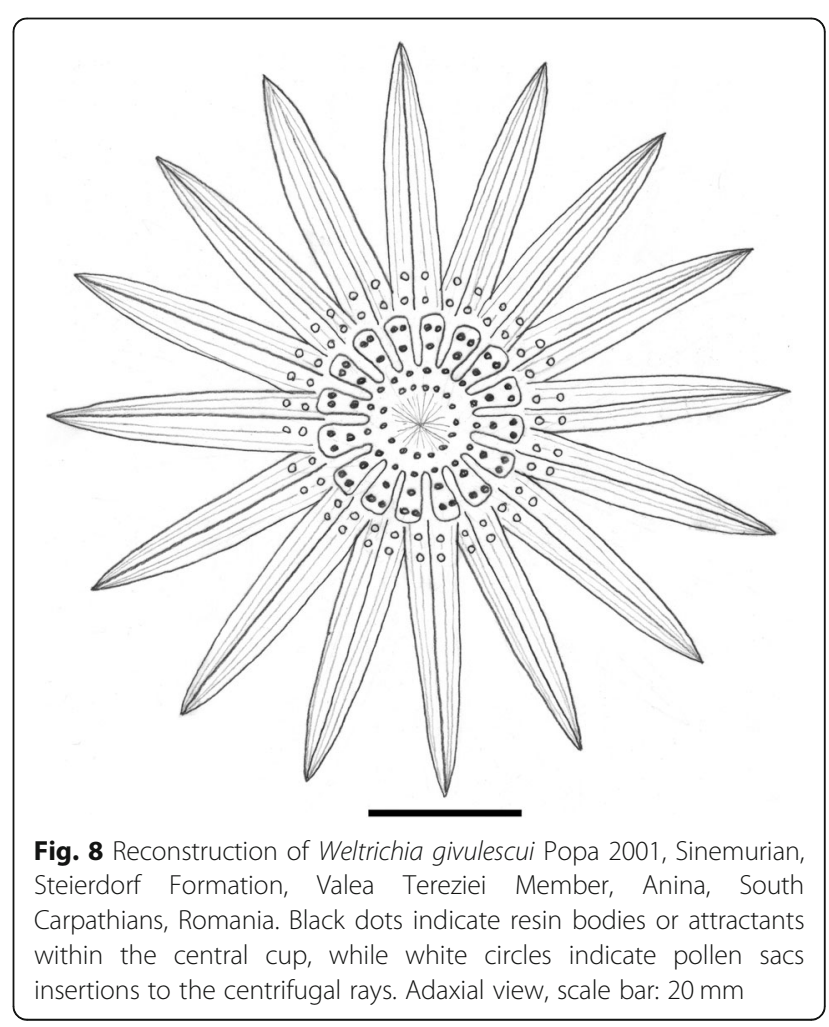


found in association with it. It was discussed by Nathorst (1911b) and Schuster (1911) and referred to by Harris (1969). It was collected from Mende, in Lozère area, France by M. Fabre, to whom this species was dedicated, from ambivalent "infraliassic sandstones of the Rhaetian stage". The material is probably Early Jurassic in age. The type series has only a single fragment, the holotype, and its repository is however unknown.

\subsection{Weltrichia givulescui Popa 2001 (Fig. 8)}

A moderately sized Weltrichia species, W. givulescui is $80-90 \mathrm{~mm}$, maximum $100 \mathrm{~mm}$ in diameter, with a central cup $30-40 \mathrm{~mm}$ in diameter. The cup height is large, of $15-20 \mathrm{~mm}$, with a base of $10 \mathrm{~mm}$ in diameter. The cup has a thick substance and it also has irregularly distributed tubercles which represented attractant or resin bodies. It has 16 triangular, elongated, centrifugal rays, $40-50 \mathrm{~mm}$ long and $7-10 \mathrm{~mm}$ wide at the base, which are rhombic in cross section, smooth, with median ridges on both adaxial and abaxial surfaces of the rays. The centrifugal rays tend to overlap superficially at their bases, still forming a single whorl. On the adaxial surface of rays occur circular to elliptic scars, possible pollen sacs badly preserved. Weltrichia givulescui has 16 centripetal rays, which are elongated, rather narrow and clearly smooth, 7-10 $\mathrm{mm}$ long and $2 \mathrm{~mm}$ wide (Fig. 8). No well-preserved pollen sacs were recorded (Popa 2001, 2014), but some scars on the centrifugal rays suggest that the pollen sacs were connected

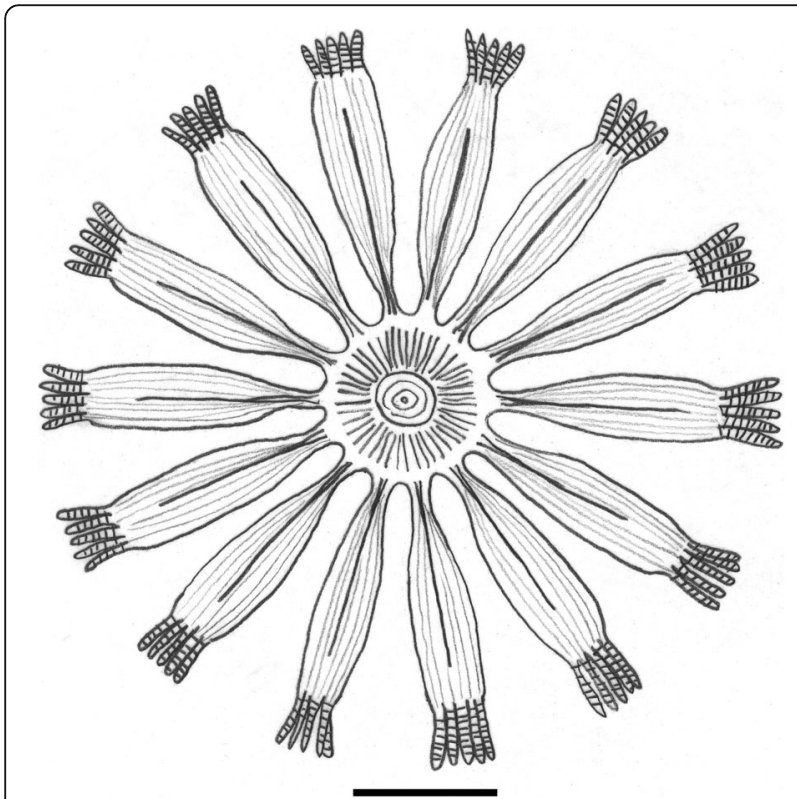

Fig. 9 Reconstruction of Weltrichia harrisiana Bose and Banerji 1984, Middle Jurassic, Kachchh, western India. Weltrichia harrisiana has five, elongated pollen sacs with apical position on the centrifugal rays. Adaxial view, scale bar: $20 \mathrm{~mm}$ directly to the rays, possibly without fertile appendages. This species is peculiar through its elongated centrifugal rays, centripetal rays and tubercles (attractants or resin bodies) on the adaxial surface of the central cup. The resin bodies or attractants are figured as black dots, while the pollen sacs insertions are figured as white circles (Fig. 8). Its affinities are related to Weltrichia johannae, also from Anina. Weltrichia givulescui is associated with Zamites aninaensis foliage (2001, 2014). Popa (2001) reconstructed this species three-dimensionally; the present reconstruction does not change it with anything, but only adds circular scars to the base of the centrifugal rays (Fig. 8). Weltrichia givulescui has been collected from Anina, Romania, from the Steierdorf Formation, Valea Tereziei Member. It is Sinemurian in age. The type series includes besides the holotype several paratypes preserved both transversally and longitudinally, curated at the Laboratory of Palaeontology, Department of Geology, Faculty of Geology and Geophysics, University of Bucharest, Romania (Popa 2001).

\subsection{Weltrichia harrisiana Bose et Banerji 1984 (Fig. 9)}

This species is about $120-150 \mathrm{~mm}$ in diameter, with a $20 \mathrm{~mm}$ diameter central cup. The central cup is striated radially and yields $12-14$ centrifugal rays. The rays are $25-35 \mathrm{~mm}$ long and $5-8 \mathrm{~mm}$ wide to their middle part. They are strongly striated longitudinally, with a thick substance, and with a prominent median ridge which is thicker towards the cup and less prominent to the apex of rays. The rays yield to their apex five pollen sacs, elongated in shape, 7-9 $\mathrm{mm}$ long and $1.5 \mathrm{~mm}$ wide, each pollen sac yielding two rows of sporangia (Fig. 9). No centripetal rays were recorded, and the pollen grains are not known (Bose and Banerji 1984). The peculiarities of Weltrichia harrisiana lay with the apical pollen sacs and with the median-inflated centrifugal rays. It has affinities with Weltrichia hirsuta from Iran, but its hair bases are very rare, and the pollen sacs are simpler, different of the apical appendages of the Iranian species. The degree of knowledge of this species is rather good, although its pollen has not been described and the number of centrifugal rays is not precisely established. The type series includes five fragments, collected from Kurbi and Kakadbhit, Kachchh region, Middle to Late Jurassic in age. The type series is stored in Birbal Sahni Institute of Palaeosciences, Lucknow, India.

\subsection{Weltrichia hirsuta Schweitzer 1977}

Weltrichia hirsuta is a peculiar and flamboyant species with centrifugal rays well developed since their basal most part, in the center of the central cup. It has an outer diameter of about $130-140 \mathrm{~mm}$. The central cup itself seems generated by the lateral fusion of the 
centrifugal rays and has a wide stalk. It has about 46 centrifugal, narrow and hairy centrifugal rays. These rays are usually fused laterally in numbers between two and six, which are very hairy along their abaxial surface and smooth or finely striated longitudinally along their adaxial surface. To the apex of each centrifugal ray occurs a pair of fertile appendages, to which elongated-elliptical pollen sacs are attached adaxially and in pairs, with a centripetal orientation of their apices. Neither centripetal rays, nor attractant or resin bodies were recorded. The typical characters of Weltrichia hirsuta are represented by its centrifugal, hairy rays which are basally fused to form the central cup, and their double fertile appendages with an apical position in each ray. It resembles superficially Weltrichia harrisiana, but in W. harrisiana the central cup is clearly defined, whose centrifugal rays are much less numerous, and the apical fertile appendages are more numerous and digitate. It is associated with Anomozamites sp. foliage. It was briefly defined and illustrated by Schweitzer (1977) and discussed later by Schweitzer and Kirchner (2003). Schweitzer (1977) gave the first reconstruction, reproduced by Schweitzer and Kirchner (2003), so a new reconstruction is not necessary here. Weltrichia hirsuta has been collected from Zangerud, Alborz Mountains, Iran, from the Shemshak Group, Upper Liassic (Sinemurian-Toarcian in age). The material is curated in the Swedish Museum of Natural History in Stockholm, Sweden.

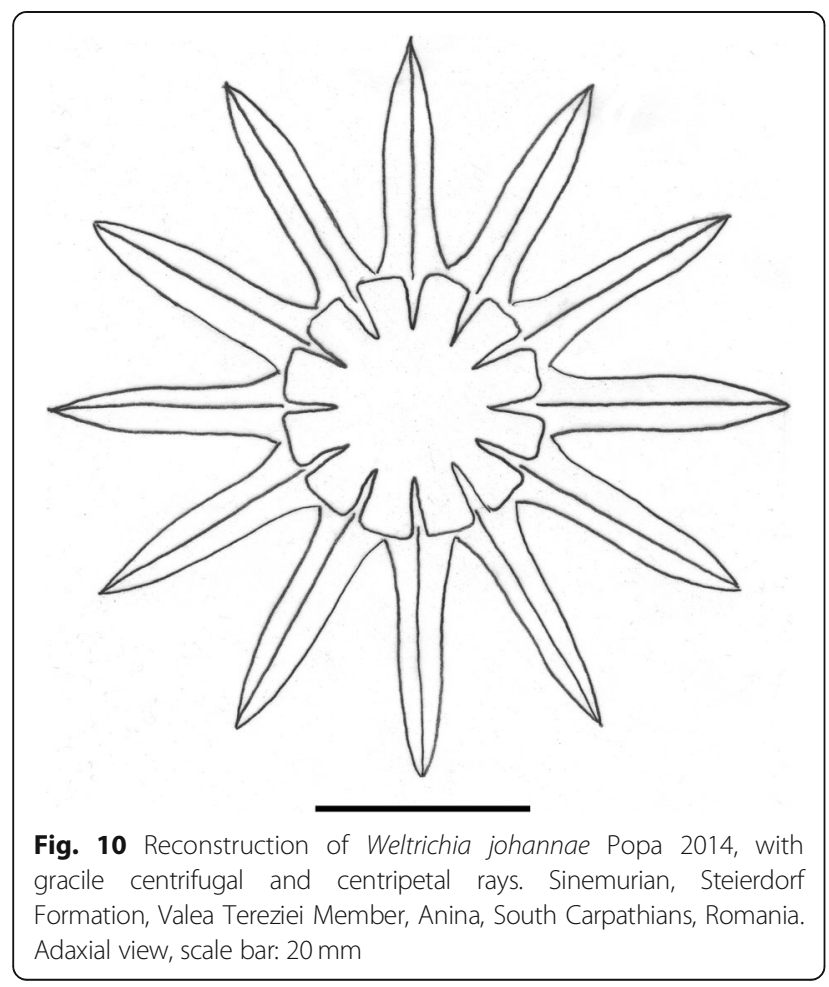

\subsection{Weltrichia huangbanjingouensis Sun et al. 2001}

This species has a long stalk of $20 \mathrm{~mm}$ long and $4 \mathrm{~mm}$ wide, and a small central cup lacking visible centrifugal rays which probably were not preserved. The central cup is $35 \mathrm{~mm}$ in diameter and $20 \mathrm{~mm}$ in height. Pollen sacs occur irregularly on the adaxial surface of the central cup (Sun et al. 2001). The degree of knowledge on this species is rather poor, as the material is not preserving centrifugal rays, although it is preserving pollen sacs in its central cup. Its peculiarities lay with the long stalk and with the pollen sacs preserved inside the central cup. It is associated with Williamsonia jianshangouensis female structure. Li et al. (2004) also observed that the material is incompletely preserved. Proposing now a reconstruction is impossible. It was collected from Huangbanjingou, Liaoning Province, China, within the lower sequence of the Yixian Formation, Late Jurassic-Early Cretaceous in age. Only the holotype was recorded, which is curated in Nanjing Institute of Geology and Palaeontology, Chinese Academy of Sciences, Nanjing, Jiangsu Province, China.

\subsection{Weltrichia johannae Popa 2014 (Fig. 10)}

A rather small, slender Weltrichia species, W. johannae is $70 \mathrm{~mm}$ in diameter, with a central cup diameter of $15 \mathrm{~mm}$. The cup has a smooth surface, and a thick substance. The species has 12 elongated, slender and flattened dorsi-ventrally centrifugal rays, with thick

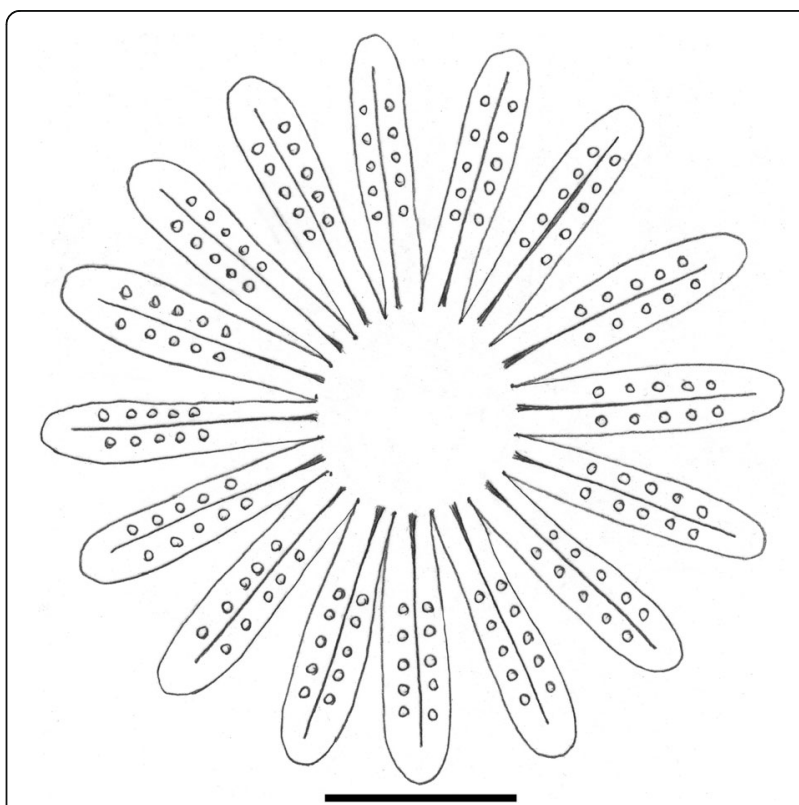

Fig. 11 Reconstruction of Weltrichia maldaensis Pal and Ghosh 1985, with spatulate centrifugal rays. Late Jurassic, Milki, West Bengal, India. Adaxial view, scale bar: $20 \mathrm{~mm}$ 
substance, smooth surfaces and with a median ridge, $25-27 \mathrm{~mm}$ long and 5-6 $\mathrm{mm}$ wide at the base. It has at least 12 centripetal rays, which are smooth, elongated, and narrow, with a sharp apex, 4-5 mm long and $1 \mathrm{~mm}$ wide at their base (Fig. 10). Neither pollen sacs, nor resin bodies or attractants were recorded (Popa 2014). The systematics affinities of Weltrichia johannae lay with $W$. givulescui, but $W$. johannae is smaller than the latter and has less centrifugal and centripetal rays. It is associated with Zamites schmiedelii foliage and with Williamsonia banatica ovulate structures. This species was collected in Anina, South Carpathians, Banat region, Romania, from the Steierdorf Formation, Valea Tereziei Member, Sinemurian in age. The type series has a holotype and a paratype, curated at the University of Bucharest, Romania.

\subsection{Weltrichia maldaensis Pal et Ghosh 1985 (Fig. 11)}

This species has a central cup with only eight centrifugal rays preserved, out of probably 16 . The central cup is 20 $\mathrm{mm}$ in diameter and about $12-15 \mathrm{~mm}$ in height. The rays are slightly concave, $25 \mathrm{~mm}$ long and $5 \mathrm{~mm}$ wide in their median part, with a median ridge on both sides and with attenuate apex. No ornamentation of the rays is visible. The pollen sacs are circular in outline, and they are arranged in two parallel rows, along each side of the median ridge (Pal and Ghosh 1985). The peculiarities of this species lay with the circular shape of the pollen sacs and with the attenuated apices of the

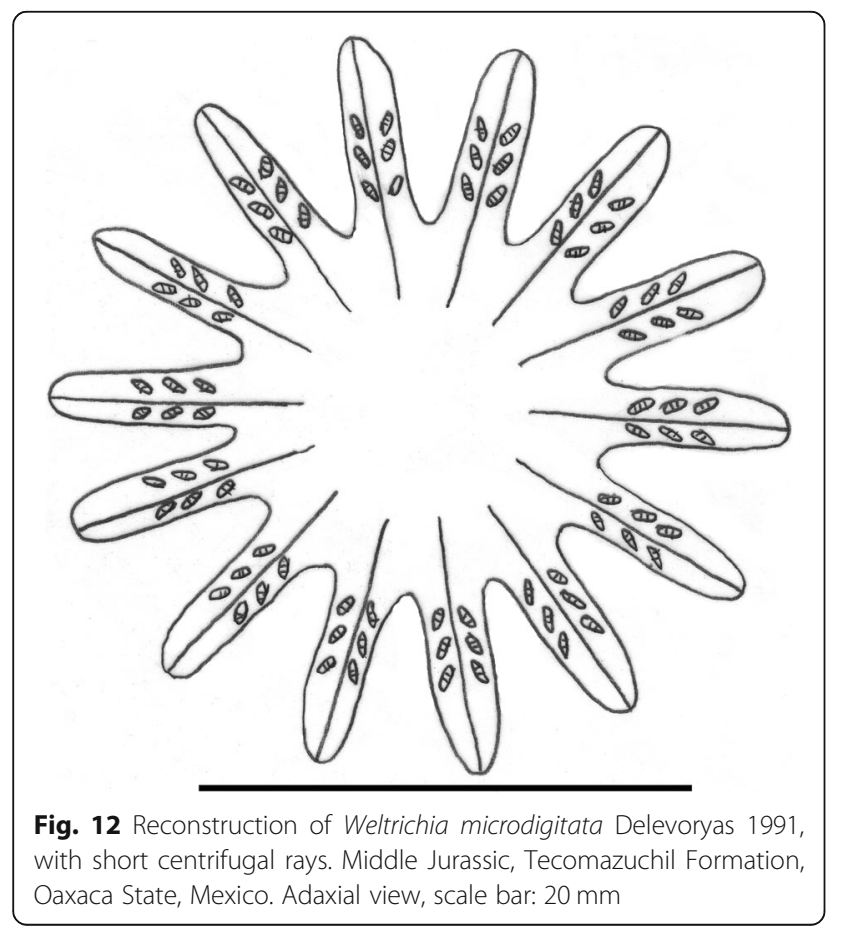

centrifugal rays (Fig. 11). The shape of the pollen sacs may be difficult to assess, if they seem to be expressed as bulges through the substance of the centrifugal rays, visible from the abaxial (outer) sides of rays. Weltrichia maldaensis is associated with Taeniopteris spatulata and Ptilophyllum sp. Pal and Ghosh (1985) considered that the structure has only half of the rays preserved. The holotype shows a Weltrichia preserved longitudinally and symmetrically, so such a conclusion makes sense. This species needs revision, as the original description is too short, and the photographic illustration is unclear. The material includes only the holotype. It was recorded from borehole samples from Milki, Malda region, West Bengal, India. The stratigraphic level of the collected material is within the intertrappean beds, between volcanic flows IV and V, Upper Jurassic, correlated with the Rajmahal Basin. The repository of the material is unknown.

\subsection{Weltrichia microdigitata Delevoryas 1991 (Fig. 12)}

Weltrichia microdigitata is the smallest species of Weltrichia, with a diameter of only $30 \mathrm{~mm}$. The shallow central cup is $15 \mathrm{~mm}$ in diameter, supporting 14 centrifugal rays. The rays are about $7-8 \mathrm{~mm}$ long, with a median ridge visible on their adaxial sides, and with rounded apices. The pollen sacs occur on the adaxial surface of centrifugal rays, along two parallel rows, at least three of them on each row (Fig. 12). They are elongated and each of them includes 15 microsporangia

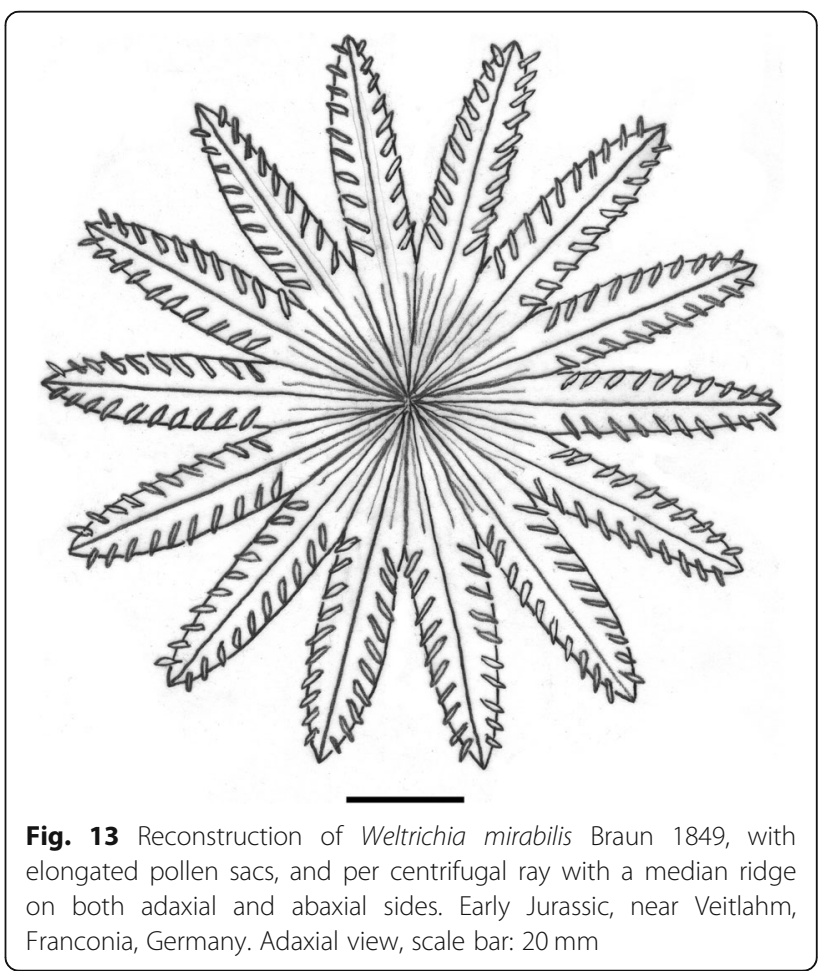


(Delevoryas 1991). The particular characters of this species are represented by size, and by the shape and number of centrifugal rays. It has no systematic affinities, resembling distantly only Weltrichia ayuquiliana from the same region. It has no other bennettitalean organs associated with it. Delevoryas (1991) did not insist on too many character descriptions, such as the tips of the centrifugal rays and the number of pollen sacs per row, still visible in his illustrations. Silva Pineda et al. (2011) and Velasco de Leon et al. (2012) discussed its stratigraphy and occurrence. It was collected from Oaxaca State, near Pena de Ayuquila, Mexico, from the Tecomazuchil Formation, Middle Jurassic in age. Only the holotype was recorded, curated at the University of Texas, Austin, United States of America.

\subsection{Weltrichia mirabilis Braun 1849 (Fig. 13)}

The type species of genus Weltrichia, W. mirabilis has a central cup to which are attached at least 10-11 centrifugal rays, with an external diameter of the structure of about $100 \mathrm{~mm}$. The central cup seems rather smooth, with radial ridges which continue as median ridges for each centrifugal ray. The cup is about $50 \mathrm{~mm}$ in diameter and $20 \mathrm{~mm}$ in height, considering the published illustrations. The centrifugal rays are triangular-elongated in shape, which seem finely striated longitudinally, at least along the abaxial surface, with the median ridge expressed on both of their sides. The rays are $30-40 \mathrm{~mm}$ long, and tend to curve inwards. Pollen sacs are attached to the adaxial side of the centrifugal rays. They are

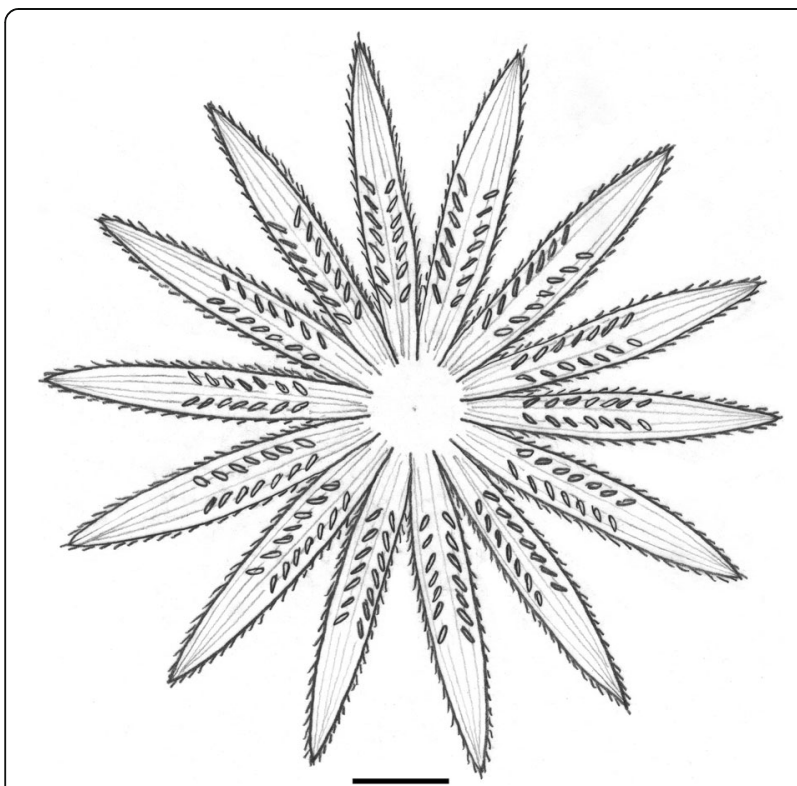

Fig. 14 Reconstruction of Weltrichia mixtequensis Silva Pineda et al. 2011, with striated and hairy centrifugal rays, elliptical pollen sacs, and a small sized central cup. Middle Jurassic, Tecomazuchil Formation, Oaxaca State, Mexico. Adaxial view, scale bar: $20 \mathrm{~mm}$ elliptical and elongated, almost perpendicular to the adaxial surface, $3-5 \mathrm{~mm}$ in length. They seem to be inserted symmetrically along two parallel rows, on both sides of each ray median ridge. Each row may have up to 20 pollen sacs, arranged in two rows of 10 pollen sacs each (Fig. 13). Rays tend to curve inwards, as the details illustrated by Braun (1849) and Nathorst (1911b) show. Next to Weltrichia mirabilis were introduced W. ovalis and $W$. campanulata, which are synonyms to $W$. mirabilis, considered as different ontogenetic stages by their author. No cuticles were preserved. The affinities of Weltrichia mirabilis are with W. fabrei defined by Saporta (1891), in terms of centrifugal rays and of pollen sacs. It is not associated with any other bennettitalean organs. It was defined and described by Braun (1849) from the Lower Jurassic of Veitlahm, near Bayreuth, Franconia, Germany. Later, Saporta (1891), Nathorst (1880, 1909, 1911b), and Schuster (1911) discussed and illustrated in detail the species. The total number of centrifugal rays is unknown. It is unclear that the rays' margins are entire or lobed, because of different interpretations of pollen sacs. The original illustrations of Braun (1849) seem without lobes, while those of Saporta (1891) are clearly lobed (his plate 37, Figs. 1, 2; plate 38, Fig. 1). The photographs made by Nathorst (1911b) show pollen sacs and centrifugal rays with entire margins. Braun's fragment illustrated in his Fig. 3 is illustrated by Nathorst (1911b) and it is curated in the Swedish Museum of Natural History in Stockholm, Sweden (Nathorst 1911b). The location of rest of the type series is unknown, probably in Uppsala, Sweden.

\subsection{Weltrichia mixtequensis Silva Pineda et al. 2011}

(Fig. 14)

This species has a small central cup, $10-20 \mathrm{~mm}$ in diameter, and about 14 centrifugal rays. The diameter of the entire structure is $160 \mathrm{~mm}$, the authors who defined this taxon correctly referring to a diameter of $80 \mathrm{~mm}$ with folded centrifugal rays. The centrifugal rays are large, 75-80 $\mathrm{mm}$ long and 7-9 $\mathrm{mm}$ wide towards their median part, with entire margins and acute apices, longitudinally striated and fibrous, without a clear median ridge, and with hairs towards the margins of the rays. The pollen sacs are arranged in rows on the adaxial side of the rays, probably in two parallel rows per ray. The pollen sacs are elongated, $1.65-5.54 \mathrm{~mm}$ long and $0.39-1.37 \mathrm{~mm}$ wide, with sporangia arranged transversally inside them (Silva Pineda et al. 2011). The visible centrifugal rays are seven, as the cone is preserved longitudinally; and the structure may not be able to accommodate 14 rays, therefore it may have had less than 14 rays (Fig. 14). The peculiar characters of Weltrichia mixtequensis lay with the shape and size of the centrifugal rays, next to the very small size of the central cup. This material of this 


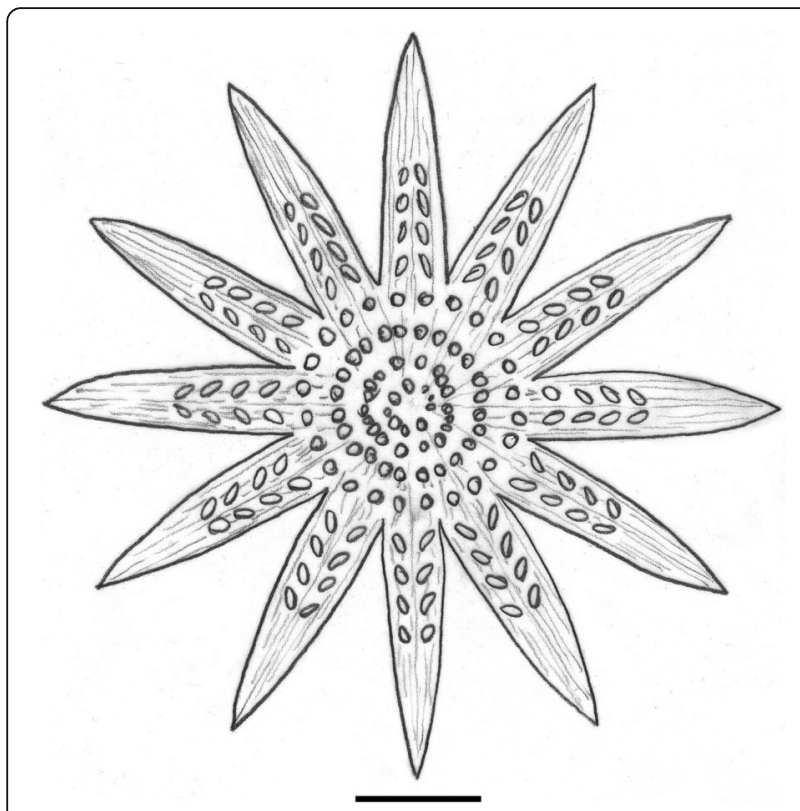

Fig. 15 Reconstruction of Weltrichia pecten (Leckenby) Harris 1969, with striated centrifugal rays, pollen sacs and resin bodies. Middle Jurassic, Yorkshire, United Kingdom. Adaxial view, scale bar: 20 mm

species is not associated with vegetative organs of Bennettitales. It was collected from the Tecomazuchil Formation, Middle Jurassic in age. The type series has ten specimens, curated at Facultad de Estudios Superiores Zaragoza, Mexico.

\subsection{Weltrichia oolithica Saporta 1891}

Weltrichia oolithica has a central cup about $40 \mathrm{~mm}$ in diameter, with an undetermined number of centrifugal rays which are $30-40 \mathrm{~mm}$ long. The illustration of the holotype (Saporta 1891: pl. 38, Fig. 2) shows at least 9 rays, as the structure is preserved longitudinally. The rays are finely striated longitudinally along their abaxial surface with entire margins, and they seem to bear fertile appendages yielding pollen sacs. Saporta (1891) refers to this structure as fluffy, emphasizing the scarcity of preserved characters. It is a less understood species of Weltrichia, mainly due to the unclear characters of the material. It resembles Weltrichia mirabilis and W. fabrei, although if the fertile appendages yield double rows of pollen sacs, it may share similar characters with W. spectabilis or W. sol. It was discussed by Nathorst (1911b) and Schuster (1911) and referred to by Harris (1969). It is difficult to propose a reconstruction, at least without revising the original material. The holotype was collected by Achille de Zigno from the Venetian Alps, reported as being Late Jurassic (Oxfordian) in age. Saporta (1891) worked on a photograph sent by de Zigno, and the storage location of the holotype is unknown.
4.17 Weltrichia pecten (Leckenby) Harris 1969 (Fig. 15)

Weltrichia pecten is usually $100-120 \mathrm{~mm}$ in diameter, having a central cup of diameter between 30 and $50 \mathrm{~mm}$ (usually $40 \mathrm{~mm}$ ), a thick substance, fibrous radial strands, and an adaxial surface covered with resin sacs. It has 10-12 centrifugal rays and no centripetal ones. The centrifugal rays are triangular, elongated, $30 \mathrm{~mm}$ long and $5-10 \mathrm{~mm}$ wide, strongly striated longitudinally because of fibrous strands, having a thick substance and without transversal wrinkles, with incurved apices. The pollen sacs are semicircular, arranged along two parallel rows per ray, with short peduncles, $3 \mathrm{~mm}$ long and $1 \mathrm{~mm}$ wide (Fig. 15). The number of pollen sacs pairs per centrifugal ray is unknown. The pollen sacs are grading into short-stalked resin bodies in the central cup which decrease in size towards the center (Harris 1969). The strongest affinities of Weltrichia pecten lay with W. whitbiensis. Weltrichia pecten is slightly smaller and less woody than W. whitbiensis, and Harris (1969) also noted that $W$. pecten probably had a tendency of opening more. Some affinities lay also with Weltrichia alfredii. The degree of knowledge over this species is rather good, considering the frequency of the fossil material, its preservation and the literature it produced. It has been discussed and illustrated by Nathorst (1909, 1911a, 1913) as Williamsonia pecten. Weltrichia pecten is associated with Ptilophyllum pecten foliage, Williamsonia leckenbyi female structures and with Cycadolepis nitens scales. It has been recorded from Cloughton Wyke and Gristhorpe, in Yorkshire, United Kingdom, from the Lower-Middle Deltaic Series, Middle Jurassic in age (Harris 1969) and from Sardinia, also Middle Jurassic (Krasser 1912). The Yorkshire material is stored in the Natural History Museum in London, United Kingdom.

\subsection{Weltrichia primaeva Schweitzer et Kirchner 2003}

This species is known only as fragments of centrifugal, complex and very large rays. The ray fragments are $60 \mathrm{~mm}$ long and $9 \mathrm{~mm}$ wide. The rays have a strong adaxial median ridge, having inserted laterally, oppositely and symmetrically leaf-like, flattened, elliptical fertile appendages with acute apices, at intervals of $7-8 \mathrm{~mm}$. The authors use the term microsporophylls for these appendages. The appendages have also a strong median ridge expressed both adaxially and abaxially, to which are laterally inserted short pedunculate, elliptical pollen sacs, arranged symmetrically in 4-5 pairs along both sides of the appendage median ridge. The peculiarity of Weltrichia primaeva is represented by the leaf-like, flattened fertile appendages, unique until now in genus Weltrichia. Weltrichia spectabilis resembles somehow $W$. primaeva, but $W$. spectabilis has filiform fertile appendages. Schweitzer and Kirchner (2003) considered this species as having a basal position in genus Weltrichia, interpreting the flattened fertile appendages 
(microsporophylls) as simple flattened leaves. They consider the lineage Weltrichia primaeva, W. spectabilis, W. sol and W. whitbiensis as a continuous evolutionary line based on the continuously reducing morphology of the fertile appendages of these species, from large and leaf-like in $W$. primaeva to no fertile appendages in $W$. whitbiensis. Weltrichia primaeva is associated with Anomozamites majus foliage. The knowledge about this species is limited by the preservation of the fossil material, as the central cup is missing, as well as the base and apices of the centrifugal rays. I refrain from proposing a reconstruction of this species. It has been collected from Alborz Mountains in Zirab, Iran, from the Shemshak Group, upper Liassic in age (Pliensbachian-Toarcian). The material is curated in the Swedish Museum of Natural History in Stockholm, Sweden.

\subsection{Weltrichia santalensis (Sitholey et Bose) Harris 1969}

This is one of the largest Weltrichia species, with an outer diameter of 220-230 mm. The central cup is striated radially along both sides, lacking attractants or resin bodies, $28-45 \mathrm{~mm}$ in diameter, $10-25 \mathrm{~mm}$ in height, and with a narrow stalk and a curved rim. It has 20 centrifugal rays, narrow and long, flattened towards the cup and strongly thickened and widened towards the apex. Pollen sacs are elongated, arranged adaxially in two parallel rows per ray. No pollen was recorded from this structure. In size, Weltrichia santalensis is similar to Weltrichia sol and W. primaeva, as the largest sized species of Weltrichia. The species was introduced by Sitholey and Bose (1953) as Williamsonia santalensis, and later Bose (1967) defined as Weltrichia singhii (now a synonym of Weltrichia santalensis). Harris (1969) correctly assigned Williamsonia santalensis to genus Weltrichia. There has been a series of discussion regarding the morphology of Weltrichia santalensis. First, it was considered that the cup and the centrifugal rays have beneath them a lower whorl of 20 sterile bracts (Sharma 1969). Secondly, it was proposed that the parallel rows of pollen sacs of each ray converge to the apical part of the centrifugal rays, and that the apical part of rays are thickened and waved adaxially, while all rays are twisted laterally (Sharma 1969, 1971, 1977). A first reconstruction of Weltrichia santalensis was proposed by Sharma (1969). Sitholey and Bose (1971) reviewed the structure and suggested that the rows of pollen sacs remain parallel, the apical parts of the rays are thickened only abaxially into a hump-like thickening and that the rays are spirally arranged and not in whorls. Banerji (1992) reviewed the genus Weltrichia in India, with a history of researches and of opinions on this species too. Weltrichia santalensis includes Ontheanthus polyandra Ganju 1947, and Williamsonia campanulatiformis Sharma 1969, while Weltrichia singhii Bose 1967 is

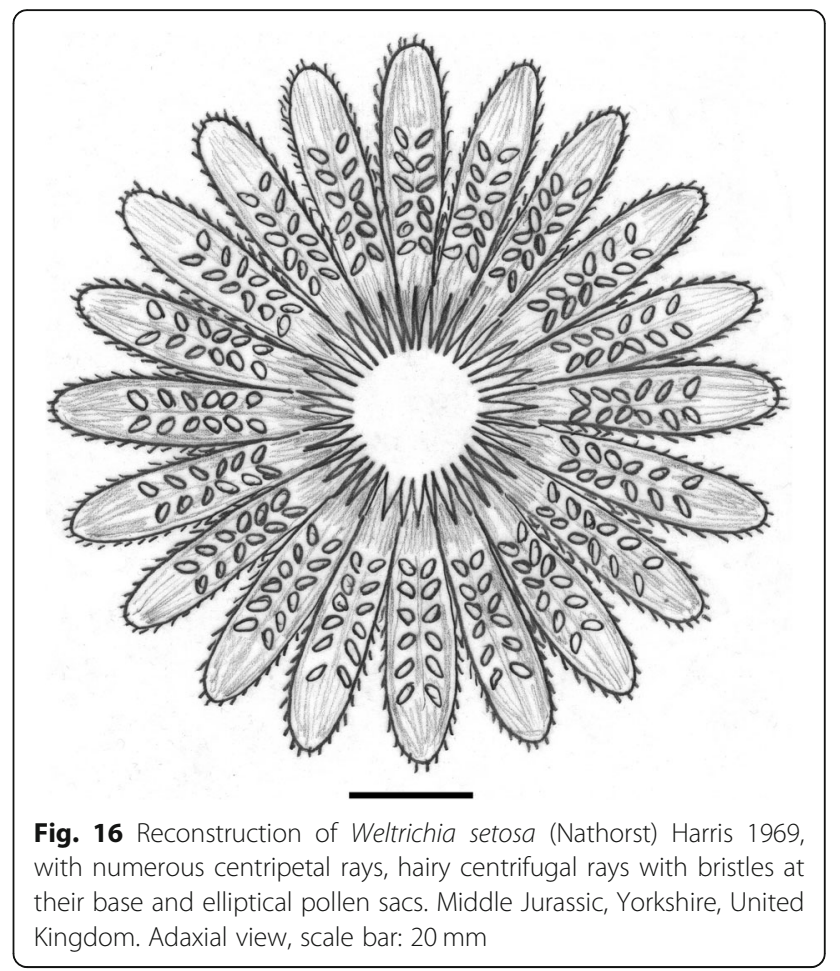

interpreted as a bud of W. santalensis (Sitholey and Bose 1953, 1971; Bose 1967; Sharma 1969, 1971, 1977; Banerji 1992). This species needs a revision of its material, mainly because the geometry of all its reconstructions does not fit the ripening and opening geometry of the initial, ellipsoidal bud, especially because of the apical widening and thickening of the rays. Realizing this geometry of accommodation of rays to an initial bud is possible when trying to draw a reconstruction of this species, which I did, only to realize that the geometry of the centrifugal rays does not fit properly. I think it was a problem which Sharma (1969) encountered too, when proposing the twisting of the rays and their adaxial thickening. It is difficult to propose a reconstruction without revising the type series. Weltrichia santalensis has been collected from Rajmahal Hills, Bihar, India, where it is Middle to Late Jurassic in age (Banerji 1992), after some interpretations even Early Cretaceous in age. The material is stored at the Birbal Sahni Institute of Palaeosciences in Lucknow, India.

\subsection{Weltrichia setosa (Nathorst) Harris 1969 (Fig. 16)}

Weltrichia setosa is about $120 \mathrm{~mm}$ in diameter, with a central cup $40 \mathrm{~mm}$ wide, and with a thick substance. To the central cup are attached 20 centrifugal rays with slightly incurved and rounded apices. The centrifugal rays are $40-60 \mathrm{~mm}$ long and $10-16 \mathrm{~mm}$ at their middle part where their maximal width occurs, $5 \mathrm{~mm}$ wide at the base, spatulate in shape, ornamented with bristles (rigid, sometimes toothed and bearing spines) and hairs (shorter, less rigid and thinner). The bristles, $3 \mathrm{~mm}$ long, 
occur to the base of the centrifugal rays, and interlock with those of the neighbor rays. The substance of the centrifugal rays is rather thick. This species has 40 elongated, linear delicate centripetal rays (about two centripetal rays per base of each centrifugal ray), $10 \mathrm{~mm}$ long and $1 \mathrm{~mm}$ wide, also covered with bristles and hairs. The margins of the centripetal rays are covered with 2-mm-long hairs. The pollen sacs are flattened, $3-7 \mathrm{~mm}$ long, arranged in two parallel rows along each centrifugal ray (Fig. 16). They have two valves and a think cuticle, which yield pollen masses. The pollen grains are ellipsoidal, $37 \mu \mathrm{m}$ long, with a slightly granular ornamentation (Harris 1969). It is associated with Otozamites beanii foliage. It was recorded only from Whitby, Yorkshire, United Kingdom, from the Middle Deltaic Series, Middle Jurassic in age. Harris (1969) considered it a rare species. The type series includes three samples, a neotype and two paratypes, curated in the Natural History Museum in London,

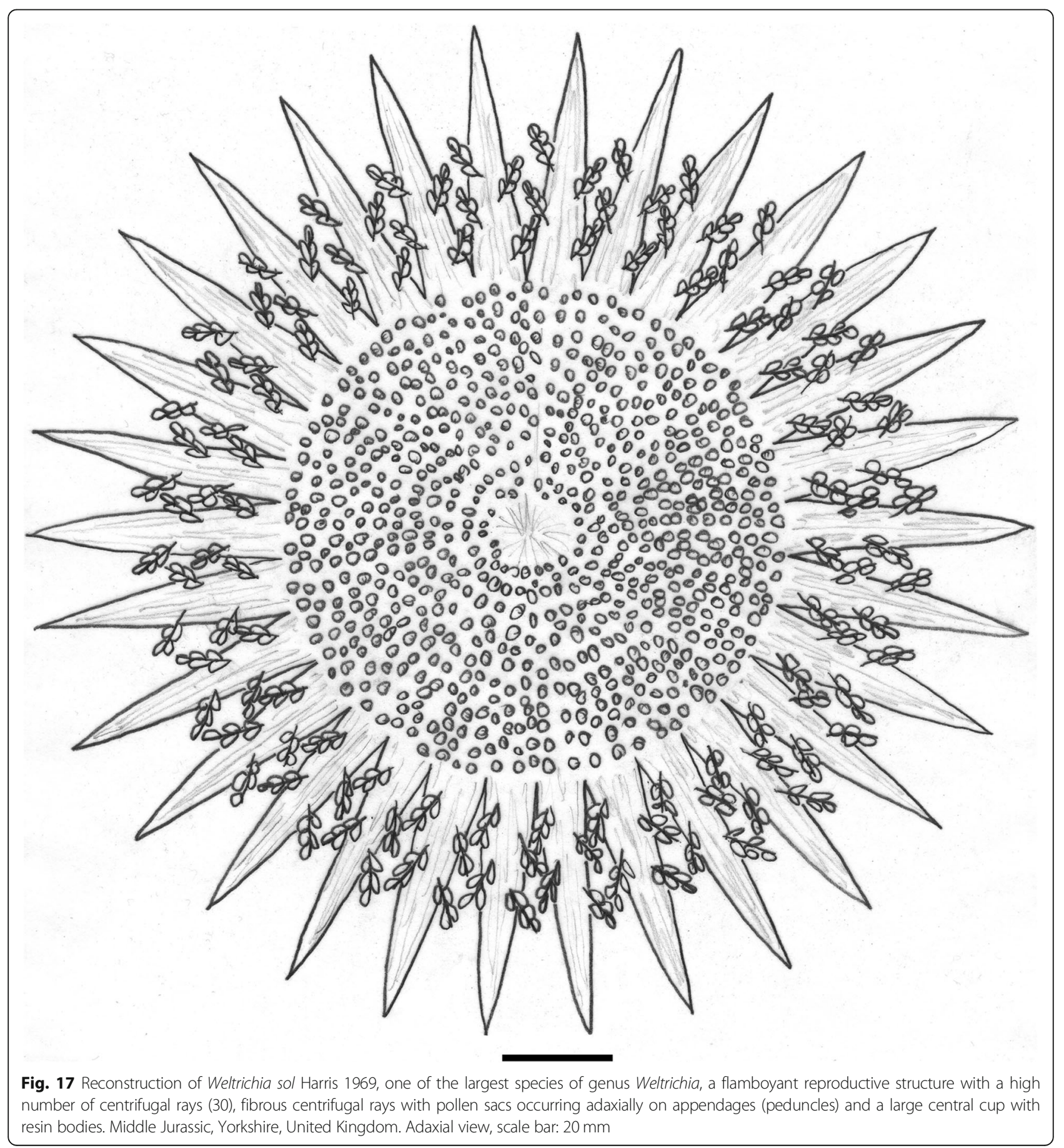


United Kingdom and in the Swedish Museum of Natural History in Stockholm, Sweden.

\subsection{Weltrichia sol Harris 1969 (Fig. 17)}

This is one of the largest species of Weltrichia, with a diameter of $170-200 \mathrm{~mm}$. The central cup is $100 \mathrm{~mm}$ in diameter, fibrous, covered with resinous, hairy sacs, with a rather thick substance, and with a height of 70-80 $\mathrm{mm}$. It has 30 centrifugal rays which are triangular and elongated, $50-60 \mathrm{~mm}$ long and about $10 \mathrm{~mm}$ wide. They are almost smooth adaxially, with longitudinal ridges (caused probably by fibers) and sometimes transverse wrinkles, and with a thick substance. It has no centripetal rays, or these were not preserved. The cuticle of the central cup and of the centrifugal rays is about $1 \mu \mathrm{m}$ thick, with syndetocheilic stomata irregularly distributed, and with thickened guard cells, small subsidiary cells and no trichome bases. The pollen sacs are pedunculate, with two pollen sacs rows associated with a long fertile appendage; each appendage is $10 \mathrm{~mm}$ long and $1 \mathrm{~mm}$ wide; and each pollen sac is $4 \mathrm{~mm}$ long and $2.5 \mathrm{~mm}$ wide. The fertile appendages are inserted more or less alternately to the adaxial side of the centrifugal rays, each appendage having four to five sacs (Fig. 17). Each pollen sac has two valves, with the outer cuticles lacking stomata. The sporangia inside the pollen sacs are about $2 \mathrm{~mm}$ long and $0.3 \mathrm{~mm}$ wide. The pollen grains are elliptical and monosulcate, $45-50 \mu \mathrm{m}$ long (Harris 1969). This is a peculiar Weltrichia species as it is of one largest structure, with the highest number of centrifugal rays, with lots of resin bodies along the adaxial surface of the central cup and with pedunculate pollen sacs. This flamboyant species was studied in detail by Harris (1969) who provided one of the most detailed accounts on a Weltrichia species, both macroscopically and microscopically (cuticles and pollen). It has been also described by Seward (1900) as a part of Williamsonia gigas structure and by Thomas (1915) as a male flower. The preservation degree of the fossil material is very good. It is associated with Zamites gigas foliage and Williamsonia gigas female structures. It has been described from Whitby and Haiburn Wyke in Yorkshire, United Kingdom, within the Middle Deltaic Series, Middle Jurassic in age. Fossil material belonging to this species is curated in the Natural History Museum in London, United Kingdom and in the National Museum of Natural History in Paris, France.

\subsection{Weltrichia sp. (sp. nov.? Figure 18)}

This Japanese species has a central cup to which are attached 15-16 centrifugal rays, about $100 \mathrm{~mm}$ in outline diameter of the structure. The cup is $27 \mathrm{~mm}$ in diameter, and is striated radially along its abaxial side, with a thick substance. The centrifugal rays are $37 \mathrm{~mm}$ long and $10 \mathrm{~mm}$ wide at the base, fibrous and striated

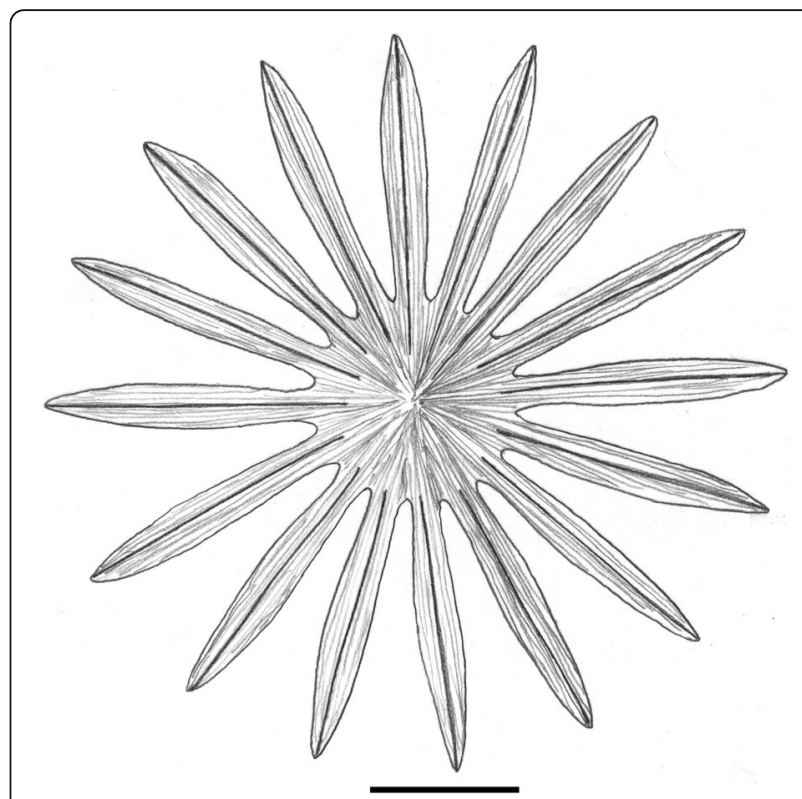

Fig. 18 Reconstruction of Weltrichia sp. (n. sp.?) of Kimura and Ohana (1989), with peculiar shaped centrifugal rays marked by a median ridge and longitudinal striations. Samenoura, NE Japan, Oginohama Formation, Oshika Group, Outer Zone of Japan. Abaxial view, scale bar: $20 \mathrm{~mm}$

longitudinally, with a strong median ridge, entire margins and slightly sharp apices, and with a thick substance (Kimura and Ohana 1989). No filiform whiskers at the tips of the rays were recorded, neither were pollen sacs or fertile appendages (Fig. 18). The peculiarities of the material are represented by the shape of the centrifugal rays which are marked by a prominent, median ridge and lacking apical whiskers, which could define quite easy a new species of Weltrichia. The affinities of this species lay mainly with Weltrichia spectabilis (Kimura and Ohana 1989), but the Japanese material is missing apical whiskers as well as any adaxial, fertile appendages. The latter, if they existed, could have been lost too due to taphonomy or to the maturity of the structure. It is associated with Zamites densipinnatus (Kimura and Ohana 1989). The structure is showing abaxial surface, which is rather well preserved, and can represent quite well a new species. It was collected from Samenoura, from the Oginohama Formation, Oshika Group, in the Outer Zone of NE Japan, Late Jurassic in age. The material includes only a single fragment, curated in the Institute of Natural History, Tokyo, Japan.

4.23 Weltrichia spectabilis (Nathorst) Harris 1969 (Fig. 19) Weltrichia spectabilis has a central cup usually $40 \mathrm{~mm}$ in diameter and $30 \mathrm{~mm}$ in height, with a short stalk. To the cup are attached 13 centrifugal rays with apical filiform extensions (or "whiskers") which are curved inwards. The rays are $30-50 \mathrm{~mm}$ long and about $10 \mathrm{~mm}$ wide at 


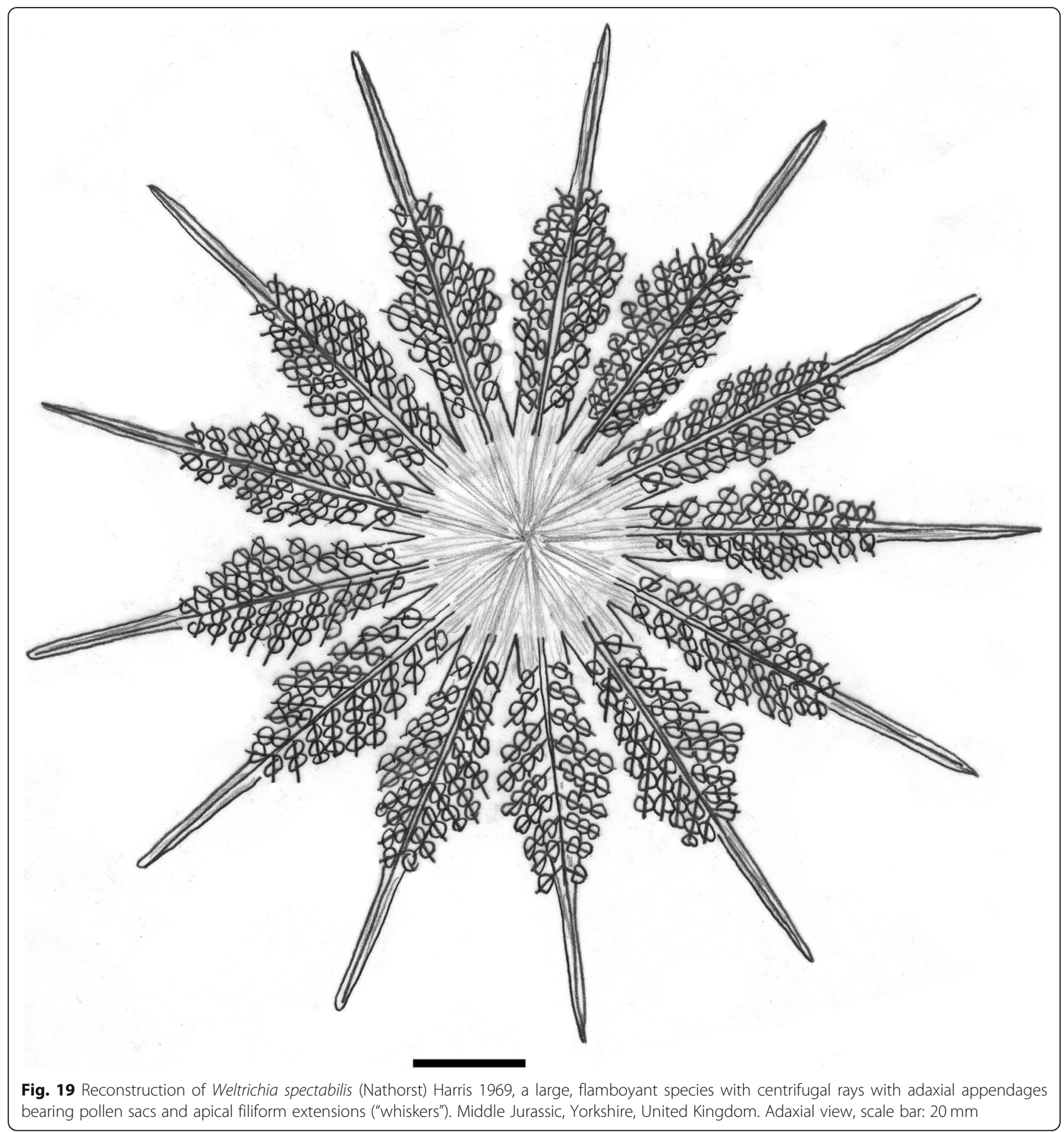

their base, while the filiform whiskers can reach $30 \mathrm{~mm}$, sometimes even $60 \mathrm{~mm}$ in length in the largest structures. The rays are strongly striated longitudinally, with transverse wrinkles and sometimes having a median ridge, mainly on their abaxial (external) surface. Along the adaxial surface of the centrifugal rays, along both sides of the median ridge, occur two rows of fertile appendages (or branches), each appendage yielding laterally and symmetrically pollen sacs. The appendages vary between 15 and $20 \mathrm{~mm}$ in length, bearing laterally 1-3 pairs of semicircular or elongated pollen sacs on each side of the appendage (Fig. 19). The pollen sacs are presumed as having two equal valves (Harris 1969), which are $1-1.5 \mathrm{~mm}$ long and include about 14 microsporangia. The pollen grains are ellipsoidal, monocolpate, psilate, and about $60 \mu \mathrm{m}$ long. The rays and cup have cuticles of moderate thickness, without hair bases, with stomata rather randomly distributed, and with 
thickened guard cells. No centripetal rays and resin bodies inside the central cup were recorded. This species is quite particular, even flamboyant in size and morphology, with its dimensions, centrifugal rays with filiform extensions, and characteristic fertile appendages with pollen sacs. The systematic affinities of Weltrichia spectabilis lay superficially only with $W$. primaeva Schweitzer and Kirchner 2003 from Iran, but W. spectabilis has simple fertile appendages. These fertile appendages also remind those of Weltrichia sol, but in W. spectabilis they are much more developed and with more pollen sacs. Weltrichia spectabilis is associated with Otozamites gramineus leaves. The degree of knowledge over this species is quite good and the works covering it are detailed, making it one of the best known Weltrichia species, next to W. pecten and W. whitbiensis. The species was defined by Nathorst (1909) as Williamsonia spectabilis, and subsequently described, illustrated and discussed by Nathorst (1911a, 1912), Thomas and Bancroft (1913), Florin (1933), Harris (1969), Schweitzer (1977) and Van Konijnenburg-van Cittert (2008). Harris (1969) emended its diagnosis and assigned it to genus Weltrichia. It has been collected from Whitby and Marske Quarry in Yorkshire, United Kingdom, from the Lower Deltaic Series, Middle Jurassic in age. Material belonging to this species is curated in the Swedish $\mathrm{Mu}$ seum of Natural History in Stockholm, Sweden, and in the Natural History Museum in London, United Kingdom.

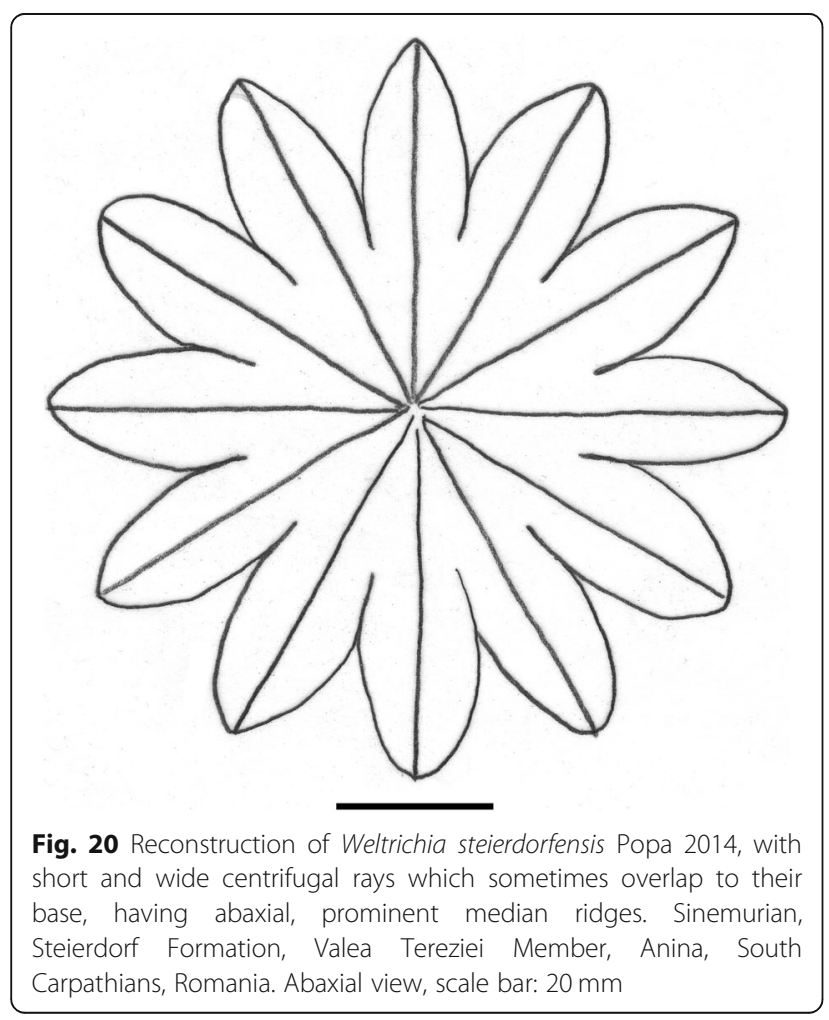

\subsection{Weltrichia steierdorfensis Popa 2014 (Fig. 20)}

This Romanian species has a diameter of about 105$120 \mathrm{~mm}$ and a central cup diameter of $40-45 \mathrm{~mm}$. The central cup has smooth abaxial surface and a thick substance, with a base $10 \mathrm{~mm}$ in diameter and about 5 $\mathrm{mm}$ in height. Weltrichia steierdorfensis has 12 centrifugal rays, $25 \mathrm{~mm}$ long, which are short triangular, with curved margins, acute apices, with a median ridge reaching the apex of each ray, and with a smooth abaxial surface. Centrifugal rays sometimes overlap as a result of taphonomy (flattening) and they tend to curve inwards (Fig. 20). No pollen sacs or cuticles were recorded. Its peculiarities are given by its large size, and by its short, centrifugal rays in a low number. It is associated with Ptilophyllum sp. leaves (Popa 2014). It was collected in Anina, Romania, within the Steierdorf Formation, Valea Tereziei Member, Sinemurian in age. The type series has only a fragment, the holotype, curated at the Faculty of Biology and Geology, Babeș-Bolyai University, ClujNapoca, Romania.

\subsection{Weltrichia whitbiensis (Nathorst) Harris 1969 (Fig. 21)}

This species is large, woody in appearance, $120-130 \mathrm{~mm}$ in diameter, with a central, almost hemispherical cup of $40-50 \mathrm{~mm}$ in diameter and at least $25 \mathrm{~mm}$ in height, with a thick substance, and with resin sacs over the adaxial surface. It has 13-16 centrifugal rays which are

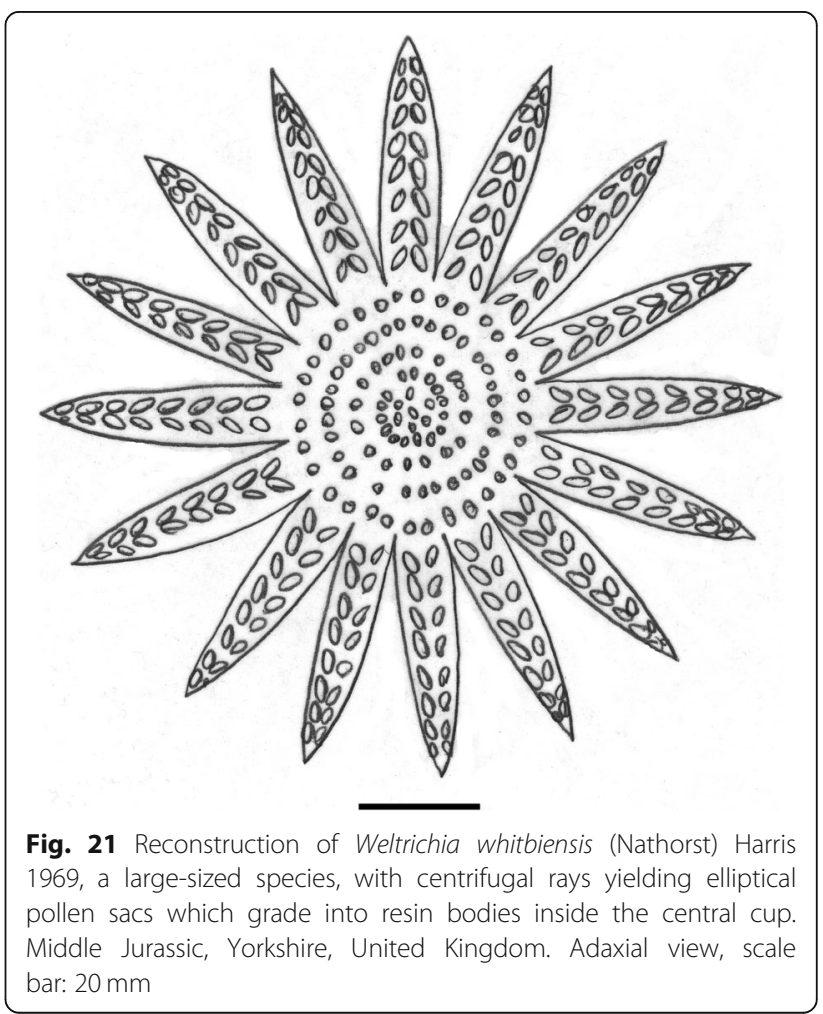


elongated, triangular, $40 \mathrm{~mm}$ long and $10 \mathrm{~mm}$ wide at their base, with a thick substance, longitudinal striations but hairless and inward-curved apices and recurved entire margins. Weltrichia whitbiensis has no centripetal rays. The pollen sacs are elliptic, 2-3 $\mathrm{mm}$ long, and are arranged in two rows along the adaxial surface of each centrifugal ray; these rows continue inside the central cup as resinous bodies. Each row has seven to eight pollen sacs, densely inserted to the centrifugal rays (Fig. 21). Pollen grains are elliptical, monosulcate, $48 \mu \mathrm{m}$ long. Harris (1969) observed the vascular bundles of this structure, distributed radially, dividing repeatedly along the central cup, six of such bundles entering each ray base, continuing parallelly and ending in the ray margins. Different bundles were feeding the pollen sacs. The morphological peculiarities of Weltrichia whitbiensis are represented by the size of the structure, and the double rows of pollen sacs grading into resinous sacs inside the central cup. Material of this species offered a glimpse into the vascular bundles of Weltrichia (Harris 1969). Discussions on Weltrichia whitbiensis were undertaken in detail by Nathorst (1911a, 1912). Weltrichia whitbiensis includes W. bituberculata Nathorst 1909 (Nathorst 1911a). It has been often confused with Weltrichia pecten, with which it has the most systematic affinities, having almost the same size, although W. pecten has a slightly lower number of centrifugal rays and is less woody (Harris 1969). Nathorst (1911a) and Schweitzer (1977) provided beautiful reconstructions of this species, although Schweitzer (1977) shows 12 pairs of pollen sacs per centrifugal ray, instead of seven to eight. Weltrichia whitbiensis is associated with Ptilophyllum pectinoides foliage, Williamsonia hildae female structures, Cycadolepis hypene scales and Bucklandia pustulosa barks (Harris 1969). It has been described from Yorkshire, United Kingdom, mainly from Whitby (Long Bright Plant Bed), but also from Roseberry, Ravenscar, Hasty Bank, Hawsker, and Beast Cliff (Harris 1969), from the Lower Deltaic Series, Middle Jurassic in age. Weltrichia whitbiensis has been described also from Sardinia (Krasser 1912), where it is also Middle Jurassic in age, but the modern revision of the historical collection of Domenico Lovisato could not confirm this species (Scanu et al. 2012). Asama (1974) referred to this species (Weltrichia sp., cf. Weltrichia whitbiensis) on fragmentary material collected from Ulu Endau, Pahang, West Malaysia, with an unknown modern repository of the published material. The Yorkshire material is curated in the Natural History Museum in London, United Kingdom.

\section{Discussion}

\subsection{Affinities}

As a unisexual, male reproductive structure, Weltrichia has a few affinities. One of the closest structures of Weltrichia is Lunzia Krasser 1917 emend. Pott et al. 2017, with the type species Lunzia austriaca (Krasser) Pott et al. 2017 from the Upper Triassic (Carnian) of Lunz, Austria. This structure has a cup shape with fused lobes bearing adaxially supplementary microsporophylls with pollen sacs yielding elliptic, monosulcate and psilate pollen grains. It is usually associated with Pterophyllum filicoides foliage and Westersheimia pramelreuthensis ovulate structure (Pott et al. 2017). As Pott et al. (2017) observed, Lunzia even fits the generic diagnosis of Weltrichia given by Harris (1969) but in the same time it is different of Weltrichia as the pollen sacs (synangia) of Lunzia occur on supplementary microsporophylls with the pollen sacs dehiscent on all sides and not made of two valves like in Weltrichia, and the syndetocheilic stomata of Lunzia have four subsidiary cells instead of the typical two in Weltrichia. Also, although the pollen grains of both genera are similar in shape and ornamentation, their sizes are very different, two to three times larger in Weltrichia (Pott et al. 2017).

Genus Welsbergia Pott et al. 2016, a segregate from genus Bennettistemon, from the Upper Triassic of Franconia and of Jameson Land, Greenland, also has affinities with Weltrichia. In Welsbergia, the centrifugal rays are transformed into narrow appendages yielding bivalve pollen sacs (Pott et al. 2016). Welsbergia bursigera (Harris) Pott et al. 2016, the only species of genus Welsbergia, is associated with Pterophyllum aequale (Brongniart) Pott et McLoughlin 2009.

Genus Bennettistemon Harris 1932 is a form-genus defined by Harris (1932) for imperfectly known male fertile fragments belonging to Bennettitales, fragments which cannot be surely attributed to Weltrichia due to various reasons, such as the poor degree of preservation. Bennettistemon is a related genus to Weltrichia, as often centrifugal rays or central cups can be easily fragmented and separated of the whole Weltrichia structure. Radial bracts surrounding an ovulate cone with ovules and interseminal scales occur in genus Williamsonia, superficially resembling Weltrichia.

An example of taxonomical difficulty related to the scarcity of the fossil material, Weltrichia mexicana (Wieland) Harris 1969 was a frequently used taxon when dealing with the Mexican Bennettitales. Wieland (1914-1916) defined the species on a single specimen collected from Diquiyu, Oaxaca State, Mexico, Lower or Middle Jurassic in age. Later Delevoryas and Gould (1973) and Person and Delevoryas (1982) rejected the 
species. They considered that this material is not a $\mathrm{Wel}$ trichia as it lacks the necessary characters, and it is impossible to assign the material to a plant taxon due to its poor preservation.

Under Weltrichia sp., Kimura et al. (1985) described and illustrated a possible Weltrichia species from the Taltung Formation of the Tansen Group in Amile, Palpa District, Lesser Himalaya, Nepal. It ranges in age between Late Jurassic and Early Cretaceous. The structure shows a deep central cup, very similar in shape with Weltrichia mexicana, with a wrinkled external surface to which possible centrifugal rays seem to be attached, possibly showing pollen sacs. It is a small sized structure and the preservation of the material is poor. The revision of the material, as in the case of Weltrichia mexicana, is necessary.

\subsection{Anatomy}

The structural variation in Weltrichia species is high, especially related to the morphology of the central cup and to number and shape of the centrifugal rays, occurrence of centripetal rays or of fertile appendages yielding pollen sacs, pollen sac contents and structure and even in the pollen itself. Original colors of Weltrichia species are difficult to identify but these colors could be related to their pollination strategy, related to insect or to wind pollination. The monoecious or dioecious nature of the bennettitaleans yielding Weltrichia and Williamsonia unisexual reproductive structures is also difficult to demonstrate due to the scarcity of the fossil record.

The substance of the central cup and of the centrifugal rays can be thin, as in Weltrichia ayuquiliana, moderately thick as in $W$. antonii, or it can be thick, as in $W$. alfredii, $W$. givulescui or $W$. spectabilis. These parts, when thick and woody, can be strongly striated longitudinally or radially, fibrous and rather rigid, versus un-ornamented when thin and flexible. Median ridges can occur in various species along both sides of the rays (Weltrichia givulescui, W. maldaensis) or they can be missing abaxially (W. alfredii) or along both surfaces. The cup itself looks like the result of lateral fusion of centrifugal rays, as in Weltrichia hirsuta, or the cup looks entire, with the rays resembling centrifugal lobes of the cup, as in W. sol or in W. steierdorfensis.

Centrifugal rays can be short (as in Weltrichia ayuquiliana) or strongly elongated with filiform apices (as in W. spectabilis), flattened (as in W. whitbiensis) or rhombic in cross section (as in W. givulescui), even spatulate (as in W. setosa). The tendency of curving of the centrifugal ray apices is also variable, higher in $W$. spectabilis, W. fabrei or W. mirabilis and missing in $W$. givulescui or $W$. alfredii. The general shape of the centrifugal rays can be triangular-elongated (W. alfredii), extremely elongated with whiskers (W. spectabilis), or reaching their maximal width towards their median part (W. harrisiana, W. maldaensis). A peculiar thickening along the abaxial, apical surface of the centrifugal rays occurs in $W$. santalensis, probably related to its ontogeny, marked by a peculiar flexed deploying (unfurling) of centrifugal rays. A bud of Weltrichia was described as Weltrichia sp. A by Popa (2014) from Anina, Romania, with centrifugal rays still connected laterally. Maturation of such a structure meant the simple deploying of centrifugal rays, without unfurling as in Cycadeoidea structures (Wieland 1906). Therefore, generating adaxial, longitudinal ridges along the centrifugal rays of Weltrichia was possible.

Due to the scarcity of the fossil record of Weltrichia species, considering that some species are represented only by their holotype, it is difficult to assess the intraspecific variability in terms of numbers of centrifugal and centripetal rays. Considering the studied material and the previous reports, the number of centrifugal and centripetal rays in Weltrichia species is rather constant.

Hairs and bristles are highly variable, occurring mainly along abaxial surfaces of cups and centrifugal rays. Extreme cases with dense trichomes belong to Weltrichia hirsuta, and with dense bristles, equipped with spike-like apices, belong to $W$. setosa.

Centripetal rays can occur in a few species (Weltrichia setosa, W. johannae, W. givulescui) or can simply miss, as a preservation effect or because those species themselves did not possess them when alive. Resin bodies or attractants (W. givulescui) and immature pollen sacs (W. sol) can occur in the central cup. The difference between these types of adaxial bodies was explained by Harris (1969) in relation to their resistance to acids: delicate, easy to macerate when being pollen sacs and difficult to macerate when being resin bodies. Pollen sacs occurring on the adaxial surface of centrifugal rays can grade into immature pollen sacs or possibly even into resin bodies, both types occurring also adaxially in the central cup. This transition can be related to the ontogeny of pollen sacs in Weltrichia, the first to mature being the pollen sacs occurring distally (apically) on the centrifugal rays.

Pollen sacs (synangia) can be elliptical as in Weltrichia pecten to strongly-elongated in shape, as in W. santalensis, W. mirabilis and W. fabrei. They can occur directly on the adaxial surface of the centrifugal rays, as in Weltrichia whitbiensis, or can occur on simple fertile appendages, as in W. spectabilis, W. sol and W. santalensis, or on complex, leaf-like appendages, as in $W$. primaeva. Fertile appendages can occur also apically, to the apex of the centrifugal rays, as in Weltrichia hirsuta or W. harrisiana, with digitate shapes. The pollen sacs always consist of two valves, but the number of 
microsporangia inside each valve can vary, although their microsporangia orientation inside the pollen sacs is usually parallel. The pollen grains are always elliptical, monocolpate and usually psilate or slightly granulate.

\subsection{Taphonomy}

Taphonomy and the degree of preservation are highly responsible with character occurrence in Weltrichia material, mainly because these complex structures could have been easily destroyed and dismembered by mechanical and biotic factors. Centripetal rays, which are always slender, thin and gracile, are preserved very rarely. Structures with centripetal rays such as Weltrichia setosa, W. givulescui and W. johannae barely preserve them. Popa (2014) showed that a part of the holotype of Weltrichia johannae shows no evidence at all of centripetal rays, while only the counterpart preserved them, acting like a lid to the central cup. Therefore, species which are reported as having no centripetal rays simply may have had lost them due to preservation and taphonomy. The same with pollen sacs, which are fragile and easily removable from the adaxial surfaces of the centrifugal rays, especially when they occurred on simple or complicated fertile appendages. Many species, such as Weltrichia givulescui, W. alfredii, etc. do not have pollen sacs recorded.

When the structures are preserved longitudinally, the total number of centrifugal rays is difficult to estimate, such as in Weltrichia mixtequensis, W. mirabilis or W. fabrei. Centripetal rays and ornamentation of the central cup is also difficult or impossible to identify, but stalks may be visible only this way. When preserved transversally, centripetal rays can be visible, as well as pollen sacs and resin bodies inside the central cups, but stalks are very difficult to observe.

Associations of organs in Bennettitales may provide a hint for the whole bennettitalean plant yielding reproductive and vegetative organs, but it cannot be a proof to it (Harris 1969; Popa 2014). Conspecificity of these organs can be only demonstrated through anatomical connections or with cuticular analysis.

\subsection{Pollination}

Form and function in Weltrichia structures are intimately controlled by the pollination strategy of these species. Two main types of pollination strategies can be invoked in relation to both unisexual and bisexual Bennettitales: wind/water pollination and insect pollination.

The wind pollination has been invoked in the case of the bennettitalean male structure Lunzia austriaca (Krasser 1917; Pott et al. 2017), based on the robust nature of the structure, on the psilate exine of the pollen grains and on the upward bending shape of its microsporophylls. Weltrichia includes similar characters, therefore wind pollination seems very plausible to many of its species. Thickness of substance, fibrous strands and strong, prominent ridges in cup and centrifugal rays in Weltrichia can be correlated with mechanical robustness and with the woody character, very well visible in $W$. spectabilis, W. alfredii, W. givulescui, $W$. whitbiensis and in many other Weltrichia species. The woody types may have been rather rigid in structural construction. Also, many species have inward curved tips of the centrifugal rays, as in Weltrichia spectabilis and W. whitbiensis. And all Weltrichia species have psilate, monosulcate pollen, all these characters pointing to a wind pollination reproductive strategy. Moreover, species with fertile appendages yielding pollen sacs on the adaxial surface of centrifugal rays (W. spectabilis, $W$. sol) or to their apices would have been in a better position to disperse their pollen using air streams.

However, there is strong and growing evidence of interactions between Bennettitales and insects, ranging from herbivory (Pott et al. 2012), leaf mining, oviposition (Pott et al. 2008; Popa and Zaharia 2011) and larvae growth inside fertile structures. In the same time, cupedid beetles began diversifying since the Late Triassic, providing candidates for insect pollination of Williamsoniaceae.

Resin bodies or attractant bodies in the central cup of Weltrichia, as occur in W. alfredii, W. givulescui and W. whitbiensis, may represent a character evolved in connection with insect pollination, particularly for cupedid pollination. Attracting insects to the center of the structure looks like a convenient strategy for dispersal of pollen. Attractants in female unisexual bennettitalean structures, such as in Wielandiella and Williamsonia, were also identified (Pott et al. 2008, 2010; Pott 2014). The thick substance of the Weltrichia structures as a whole or of their parts, such as cups and both types of rays, their mechanical robustness and their woody nature in some Weltrichia species, can be interpreted also as an adaptation against beetle biting and chewing, as beetles generally and cupedids particularly have strong masticatory parts.

Insect repellent means are more clearly expressed in Weltrichia. Centripetal rays were covering the central cup, and in one species (Weltrichia givulescui) they occur also over resin bodies or attractants. These centripetal rays in Weltrichia givulescui were rigid, considering their thickness. Covering resin bodies or attractants meant still attracting beetles but also preserving these bodies against insect damages, a strategy towards beetles outlined as "visit but do not damage". In Weltrichia johannae, the centripetal rays were rigid and sharp. Also, dense and strong hairs and complicated, sharp and spike-like bristles along the abaxial surfaces of centrifugal rays and central cups, as those of Weltrichia setosa, functioned as some types of repellents for insects. 
Moreover, Weltrichia setosa has centripetal rays covered with forward pointing hairs, although these hairs were not so rigid and sharp as those from the centrifugal rays. Interlocking abaxial bristles and hairs between centrifugal rays in Weltrichia setosa meant also a supplementary protection against insect access and damage from below.

\section{Conclusions}

Genus Weltrichia is a rare male bennettitalean reproductive structure with a peculiar anatomy, highly diverse in morphology, with its form and function controlled by the pollination strategy of the bennettitalean plant. Wind pollination seems to be the dominant strategy in Weltrichia, but hints for insect pollination, particularly for cupedid beetle pollination, occur as well in the anatomy of this genus, related to resin or attractant bodies inside the central cup and to centripetal rays of various species. The high morphological variability represents a highly interesting aspect in bennettitalean systematics and reproductive strategies. Co-evolution with insects, especially with the cupedid group, may well explain such variability of the genus Weltrichia, related to dedicated species of pollinators and pointing to specialized collaborations between bennettitaleans and insect species already occurring in the Late Triassic and the Early Jurassic. Far from being well understood in form and function, genus Weltrichia still raises a series of unanswered questions regarding various characters of some of its species, such as the architecture and colors of centrifugal and centripetal rays, resin bodies and attractants, pollen sacs and microsporangia structures, and pollen morphology and dispersal. The monoecious or dioecious nature of such Williamsoniaceae plants having unisexual reproductive structures of Weltrichia and Williamsonia types remains also a matter of debate. Whole plant reconstructions are still difficult to demonstrate, but organ associations together with cuticle analysis provide the necessary means for reaching this goal.

\section{Abbreviations}

CC: Central cup; CFR: Centrifugal ray; CPR: Centripetal ray; FS: Fibrous strand; MR: Median ridge; PS: Pollen sac position (pollen sac attachment); RBA: Resin (resinous) body or attractant; ST: Stalk

\section{Acknowledgements}

The author wishes to thank Dr. Hideo Takimoto and Dr. Atsushi Yabe (Japan) for their kind help with Japanese palaeobotanical literature. The author acknowledges the constructive peer-reviews of Prof. Maria Barbacka (Hungary) and Prof. Yong-Dong Wang (China), both improving the quality of the manuscript, and also Dr. Xiu-Fang Hu (China) for her editorial help and kind advice. This contribution is a result from the following projects: the Romanian National University Research Council (NURC-CNCSIS) research grant no. 436/2007 "Ecoter" and the IGCP 632 project "Major Extinction Events and Environmental Changes within Lacustrine Ecosystems".

\section{Authors' contributions}

This paper is a contribution of one author. The author read and approved the final manuscript.

\section{Competing interests}

The author declares that he has no competing interests.

\section{Publisher's Note}

Springer Nature remains neutral with regard to jurisdictional claims in published maps and institutional affiliations.

Received: 6 March 2018 Accepted: 20 November 2018

Published online: 27 February 2019

\section{References}

Asama, K. 1974. Weltrichia (male Williamsonia) from ulu Endau, West Malaysia. In Geology and Palaeontology of Southeast Asia, ed. T. Kobayashi and R. Toriyama, 83-88. Tokyo: Tokyo University Press.

Banerji, J. 1992. Life and time of Indian Williamsonia. The Paleobotanist 40: 245-259.

Bose, M.N. 1967. Weltrichia singhii n. Sp. from the Rajmahal Hills, Bihar. Current Science 36 (2): 48-49.

Bose, M.N., and J. Banerij. 1984. The fossil floras of Kachh. I Mesozoic megafossils. The Palaeobotanist 33: 1-189.

Braun, C.F.W. 1849. Weltrichia, eine neue Gattung fossiler Rhizantheen. Flora 32: 705-712.

Delevoryas, T. 1991. Investigations of north American cycadeoids: Weltrichia and Williamsonia from the Jurassic of Oaxaca, Mexico. American Journal of Botany 78 (2): 177-182.

Delevoryas, T., and R.E. Gould. 1973. Investigations of north American cycadeoids: Williamsonian cones from the Jurassic of Oaxaca, Mexico. Review of Palaeobotany and Palynology 15 (1): $27-42$.

Doyle, J. 2006. Seed ferns and the origins of angiosperms. Journal of the Torrey Botanical Society 133: 169-209.

Florin, R. 1933. Studien uber die Cycadales des Mesozoikums. Zur kenntnis der Spaltungsapparate der Bennettitales Kungl. Svenska Vetenskapsakademiens Handlingar 12 (5): 1-134.

Friis, E.M., P. Crane, and A.K. Pedersen. 2011. Early flowers and angiosperm evolution. Cambridge: Cambridge University Press.

Givulescu, R. 1990. Zwei neue Bennettitenblutten aus dem Unteren Lias von Anina (Banat, Rumanien). Documenta Naturae 59: 1-7.

Harris, T.M. 1932. The fossil flora of Scoresby sound, East Greenland. Part 3: Caytoniales and Bennettitales. Meddelelser om Gronland 85: 1-133.

Harris, T.M. 1969. The Yorkshire Jurassic Flora. Part 3: Bennettitales. London: British Museum (Natural History).

Hilton, J., and R.M. Bateman. 2006. Pteridosperms are the backbone of seed plant phylogeny. Journal of the Torrey Botanical Society 133: $119-168$.

Humml, H. 1969. Contributii la flora fosilă a Liasicului inferior de la Steierdorf-Anina. Studii şi cercetări de geologie, geofizică, geografie, Sectia geologie 14: 385-404.

Kimura, T., M.N. Bose, and H. Sakai. 1985. Fossil plants from Taltung formation, Palpa District, Nepal, lesser Himalaya. Bulletin of the National Science Museum Series C Geology and Paleontology 11 (4): 141-153.

Kimura, T., and T. Ohana. 1989. Late Jurassic plants from the Oginohama formation, Oshika group in the outer zone of Northeast Japan (II). Bulletin of the National Science Museum 15: 53-70.

Krasser, F. 1912. Williamsonia in Sardinien. Sitzungsber. Akad. Wissensch. in Wien 121: 943-973.

Krasser, F. 1913. Die fossile Flora der Williamsonien bergenden Juraschichten von Sardinien. Anzeig. Akad. Wissensch 4: 31-36.

Krasser, F. 1915. Männliche Williamsonien aus dem Sandsteinschiefer des unteren Lias von Steierdorf im Banat. Denkschriften der mathem.-naturw. Klasse 93: 1-18.

Krasser, F. 1917. Studien über die fertile region der Cycadophyten aus den Lunzer-Schichten: Mikrosporophylle und männliche Zapfen. Denkschriften der mathem.-naturw. Klasse 94: 489-554.

Krasser, F. 1919. Ein neuen Typus einen mannlichen Williamsonia Becherblute aus der Alpinen Trias. Sitzungsberichte der Akademie der Wissenschaften Wien, Math. natw. Kl. Abt I 128: 1-10. 
Krasser, F. 1922. Zur Kenntnis einiger fossiler Floren des unteren Lias den Sukzessionstaaten von Ostereich-Ungarn. Sitzungsberichte d. mathem.-naturw. Kl. 1: 345-373.

Li, N., Y. Li, L.X. Wang, S.L. Zheng, and W. Zhang. 2004. A new species of Weltrichia Braun in North China with a special bennettitalean male reproductive organ. Acta Botanica Sinica 46 (11): 1269-1275

Nathorst, A.G. 1880. Nagra anmarkningar om Williamsonia Carruthers. Ofversight Kongl. Ventenskaps - Akademiens Forhandlingar 9: 3-52.

Nathorst, A.G. 1909. Palaobotanische mitteilungen. 8. Uber Williamsonia, Wielandia, Cycadocephalus und Weltrichia. Kungl. Svenska Vetenskapsakademiens Handlingar 45: 1-38.

Nathorst, A.G. 1911a. Paleobotanische Mitteilungen. 9. Neue Beitrage zur Kenntnis der Williamsonia-Blutten. Kungl. Svenska Vetenskapsakademiens Handlingar 46: 1-33.

Nathorst, A.G. 1911b. Bemerkungen uber Weltrichia Fr. Braun. Arkiv fur Botanik 11: 1-10.

Nathorst, A.G. 1912. Die Mikrosporophylle von Williamsonia. Arkiv fur Botanik 12: 1-10

Nathorst, A.G. 1913. How are the names Williamsonia and Wielandiella to be used? A question of nomenclature. Geologiska foreningens Forhandlingar 35: 361-366.

Pal, A.K., and S.C. Ghosh. 1985. Weltrichia (male Williamsonia) from the borehole samples of Malda, West Bengal. Current Science 54: 574-576.

Person, C.P., and T. Delevoryas. 1982. The middle Jurassic flora of Oaxaca, Mexico. Palaeontographica Abteilung B 180 (4-6): 82119

Popa, M.E. 1997. Corystospermal pteridosperms in the Liassic continental deposits of Romania. Acta Palaeontologica Romaniae 1: $81-87$.

Popa, M.E. 2001. Aspects of Romanian Early Jurassic palaeobotany and palynology. Part IV. A new species of Weltrichia from Anina. Studia Universitatis Babeş-Bolyai, Geologie 46: 69-76..

Popa, M.E. 2014. Early Jurassic bennettitalean reproductive structures of Romania. Palaeobiodiversity and Palaeoenvironments 94 (2): 327-362.

Popa, M.E., and A. Zaharia. 2011. Early Jurassic ovipositories on bennettitalean leaves from Romania. Acta Palaeontologica Romaniae 7: 285-290.

Pott, C. 2014. A revision of Wielandiella angustifolia, a shrub-sized bennettite from the Rhaetian-Hettangian of Scania, Sweden, and Jameson land, Greenland. International Journal of Plant Sciences 175 (4): 467-499.

Pott, C., T. Fischer, and B. Aschauer. 2017. Lunzia austriaca - A bennettitalean microsporangiate structure with Cycadopites-like in situ pollen from the Carnian (upper Triassic) of Lunz, Austria. Grana 56: 321-338.

Pott, C., M. Krings, H. Kerp, and E.M. Friis. 2010. Reconstruction of a bennettitalean flower from the Carnian (upper Triassic) of Lunz, Lower Austria. Review of Palaeobotany and Palynology 159 (1): 94-111.

Pott, C., C.C. Labandeira, M. Krings, and H. Kerp. 2008. Fossil insect eggs and ovipositional damage on bennettitalean leaf cuticles from the Carnian (upper Triassic) of Austria. Journal of Paleontology 82 (4): 778-789.

Pott, C., S. McLoughlin, S.Q. Wu, and E.M. Friis. 2012. Trichomes on the leaves of Anomozamites villosus sp. nov. (Bennettitales) from the Daohugou beds (middle Jurassic), Inner Mongolia, China: Mechanical defence against herbivorous arthropods. Review of Palaeobotany and Palynology 169: 48-60.

Pott, C., S. Schmeissner, G. Dutsch, and J.H.A. Van Konijnenburg-van Cittert. 2016. Bennettitales in the Rhaetian flora of Wustenwelsberg, Bavaria, Germany. Review of Palaeobotany and Palynology 232: 98-118.

Saporta, G.D. 1891. Paléontologie française. Plantes jurassiques. Paris: Masson.

Scanu, G.G., E. Kustatscher, and P. Pittau. 2012. The Jurassic plant fossils of the Lovisato collection: Preliminary notes. Bollettino della Società Paleontologica Italiana 51: 71-84.
Schuster, J. 1911. Weltrichia und die Bennettitales. Kungl. Svenska Vetenskapsakademiens Handlingar 46: 1-57.

Schweitzer, H.-J. 1977. Die Rhato-Jurassischen Floren des Iran und Afganistans 4. Die ratische Zwitterblute Irania hermaphroditica nov. spec. Und ihre Bedenirtrung fur die Phylogenie du Angiospermen. Palaeontographica Abteilung B 161: 98-145.

Schweitzer, H.-J., and M. Kirchner. 2003. Die Rhato-Jurassichen Floren des Iran und Afghanistans. 13. Cycadophyta III. Bennettitales. Palaeontographica Abteilung B 264: 1-166.

Seward, A.C. 1900. Catalogue of the Mesozoic plants in the Department of Geology, British museum (natural history). In The Jurassic Flora, I - the Yorkshire coast. London: British Museum.

Sharma, B. 1969. Further observations on Williamsonia santalensis Sitholey and Bose with the description of a new species. Palaeontographica Abteilung B 125: 92-102.

Sharma, B. 1971. On a collection of bennettitalean stems and fructifications from Amarjola in the Rajmahal Hills, India. Palaeontographica Abteilung B 135: 48-52.

Sharma, B.D. 1977. Indian Williamsonias: An illustrated review. Acto Palaeontologica Polonica 18: 19-29.

Silva Pineda, A., M.P. Velasco de León, J.A. Gil, and J.R. Grimaldo. 2011. Una nueva especie de Weltrichia (Bennettitales) del Jurásico Medio de la Formación Tecomazuchil (Oaxaca, México), Geobios, 519-525. Lyon: Elsevier.

Sitholey, R., and M.N. Bose. 1953. Williamsonia santalensis sp. nov., a male fructification from the Rajmahal Hills with remarks on Ontheanthus polyandra Ganju. The Palaeobotanist 2: 29-39.

Sitholey, R., and M.N. Bose. 1971. Weltrichia santalensis (Sitholey \& Bose) and other bennettitalean male fructifications from India. Palaeontographica Abteilung B 131: 151-159.

Stewart, W.N. 1983. Paleobotany and the evolution of plants. Cambridge: Cambridge University Press.

Sun, G., S.L. Zheng, D.L. Dilcher, Y.D. Wang, and S.H. Mei. 2001 Early angiosperms and their associated plants from Western Liaoning, China, 1st edition. Shanghai: Scientific and Technological Education Publishing House (in Chinese).

Taylor, T.N., E.L. Taylor, and M. Krings. 2009. Paleobotany: The biology and evolution of fossil plants. Amsterdam: Elsevier.

Thomas, H.H. 1915. On some new and rare Jurassic plants from Yorkshire: The male flower of Williamsonia gigas (Lindl. \& Hutt.). Proceedings of the Cambridge Philosophical Society 69: 223-251.

Thomas, H.H., and N. Bancroft. 1913. On the cuticles and fossil cycadean fronds. Transactions of the Linnean Society of London 8: 155-204.

Van Konijnenburg-van Cittert, J.H.A. 2008. The Jurassic fossil plant record of the UK area. Proceedings of the Geologists Association 119 (1): 59-72.

Velasco de Leon, M.P., E.L. Ortiz-Martinez, and A. Silva Pineda. 2012 La distribucion de las Bennettitales y sus estructuras reproductoras en el terreno Mixteco. Paleontologia Mexicana 62: 159-165.

Wieland, G.R. 1906. American Fossil Cycads, volume 1, 256. Washington DC.: Carnegie Institution of Washington Publication 34.

Wieland, G.R. 1914-1916. La flora liasica de la Mixteca Alta. Boletin del Instituto Geologico de Mexico 31: 1-165. 